\title{
Viability of Existing INL Facilities for Dry Storage Cask Handling
}

Randy Bohachek

Charles Park

Bruce Wallace

Phil Winston

Steve Marschman

April 2013

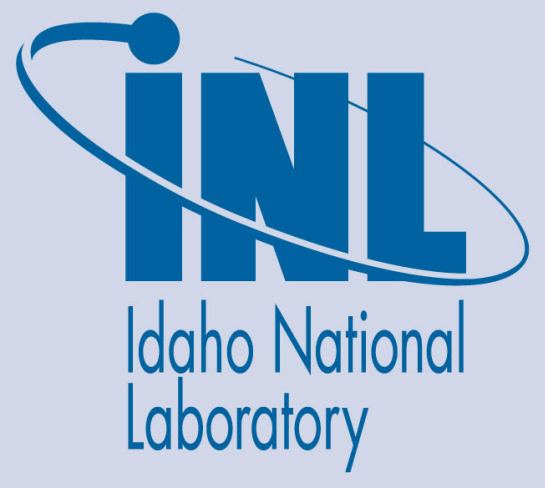

The INL is a U.S. Department of Energy National Laboratory operated by Battelle Energy Alliance 
INL/EXT-13-29035

FCRD-UFD-2013-000027

\title{
Viability of Existing INL Facilities for Dry Storage Cask Handling
}

\author{
Randy Bohachek \\ Charles Park \\ Bruce Wallace \\ Phil Winston \\ Steve Marschman
}

April 2013

\author{
Idaho National Laboratory \\ Fuel Cycle Research and Development \\ Idaho Falls, Idaho 83415
}

http://www.inl.gov

Prepared for the

U.S. Department of Energy

Office of Nuclear Energy

Under DOE Idaho Operations Office

Contract DE-AC07-05ID14517 


\section{DISCLAIMER}

This information was prepared as an account of work sponsored by an agency of the U.S. Government. Neither the U.S. Government nor any agency thereof, nor any of their employees, makes any warranty, expressed or implied, or assumes any legal liability or responsibility for the accuracy, completeness, or usefulness, of any information, apparatus, product, or process disclosed, or represents that its use would not infringe privately owned rights. References herein to any specific commercial product, process, or service by trade name, trade mark, manufacturer, or otherwise, does not necessarily constitute or imply its endorsement, recommendation, or favoring by the U.S. Government or any agency thereof. The views and opinions of authors expressed herein do not necessarily state or reflect those of the U.S. Government or any agency thereof. 
This page intentionally left blank. 


\title{
Viability of Existing INL Facilities for Dry Storage Cask Handling
}

FCRD-UFD-2013-000027

\author{
Revision 1 \\ April 30, 2013
}

Peer Review:

Electronic signature on file

April 29, 2013

Brady D. Hanson

Pacific Northwest National Laboratory

Date

Concurrence:

Electronic signature on file

April 29, 2013

Ken B. Sorenson, S\&T Control Account Manager

Sandia National Laboratory

Date

Submitted by:

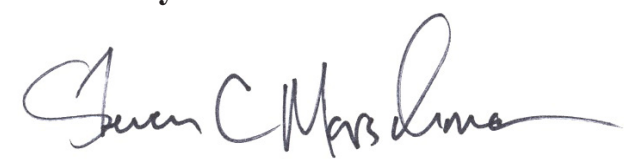

April 29, 2013

Steven C. Marschman

Date

Idaho National Laboratory 
Viability of Existing INL Facilities for Dry Storage Cask Handling

April 30, 2013

This page intentionally left blank. 


\section{SUMMARY}

This report fulfills the M2 milestone, M2FT-13IN0802027, develop and issue "Long Term Used Nuclear Fuel Storage Viability Report" under Work Package Number FT-13IN080202.

The Test Area North Hot Shop at the Idaho National Laboratory (INL) site was integral to the development of used nuclear fuel dry storage methodologies. The dry storage demonstrations conducted at the Hot Shop in the 1980s and 1990s involved low burnup used fuel. Lacking a long-term mission, that facility was decommissioned and demolished in 2007. Used nuclear fuel continues to be dry stored awaiting a final disposition pathway. The nuclear industry continues to evolve and fuels are being used that are specifically designed to achieve a high burnup (i.e., greater than 45 gigawatt-days/metric tonne uranium). While dry storage technologies are some of the safest in the world, the U.S. Department of Energy is planning a confirmatory dry storage project for high burnup fuel. The project will utilize actual storage casks that will require opening for cask and fuel examination.

This report evaluates existing capabilities at INL to determine if a practical and cost effective method could be developed for handling and opening full-sized dry storage casks similar to the Hot Shop. CPP-603, Irradiated Spent Fuel Storage Facility, at the Idaho Nuclear Technology and Engineering Center provides the infrastructure to support handling and examining of casks and their contents. The weight of the full-sized dry storage casks requires mobilizing a portable gantry crane to move the casks into the fuel-handling cave, where casks can be opened and contents examined.

The use of a portable gantry crane inside CPP-603 was chosen to provide the lowest cost of a one-to-three-cask campaign, while leaving flexibility to handle future casks for a relatively small incremental cost. Demobilizing the gantry crane after the campaign leaves CPP-603 intact to continue its existing operation, avoids the potential long-term facility and equipment maintenance costs that could be applied if the facility was modified significantly for this project.

Based on a reasonable set of assumptions, it is possible to receive, open, inspect, remove samples, close, and reseal large, bolted-lid, dry storage casks at INL. The capability also can be used to open and inspect casks that were last examined at the Test Area North Hot Shop over 10 years ago. The Castor V/21 and REA2023 casks can provide additional confirmatory information regarding the extended performance of low-burnup (i.e., less than 45 gigawatt-days/metric tonne uranium) used nuclear fuel. 
Once a dry storage cask is opened inside CPP-603, used fuel retrieved from the cask can be packaged in a shipping cask and sent to a laboratory for testing. Testing at INL's Materials and Fuels Complex (MFC) starts with shipment of samples from CPP-603 over an onsite road, avoiding the need to use public highways. This reduces costs and risks to the public. The full suite of characterization methods needed to establish the condition of the fuel exists at MFC. Many other testing capabilities also exist at MFC; however, if those capabilities are not adequate, samples can be prepared and shipped to other laboratories for testing.

This report discusses how the casks would be handled, what work needs to be done to ready the facilities/capabilities, and what the work will cost. 


\section{CONTENTS}

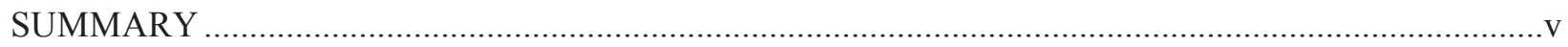

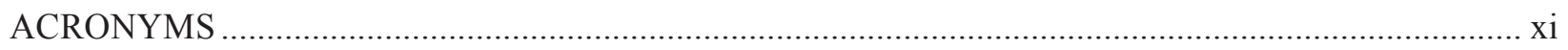

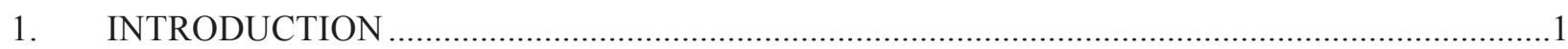

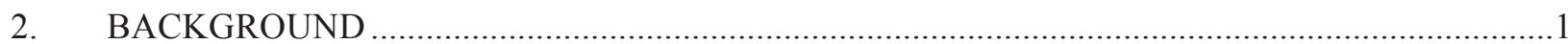

3. SCOPE

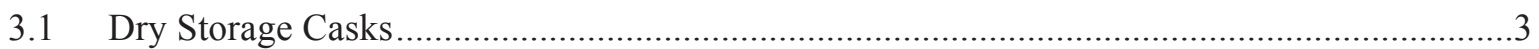

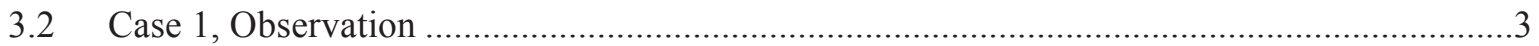

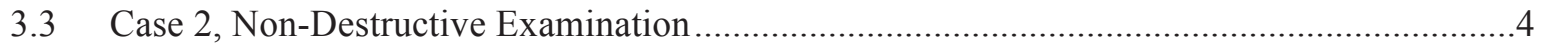

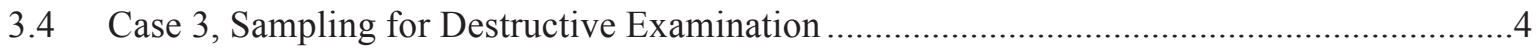

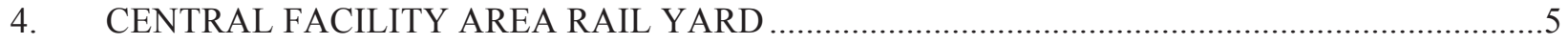

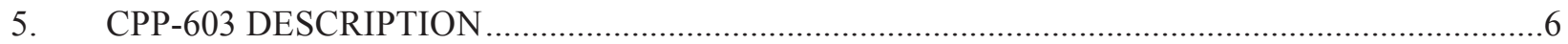

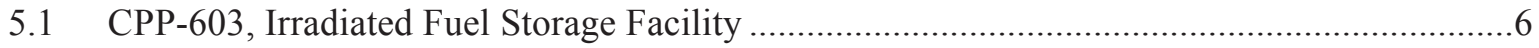

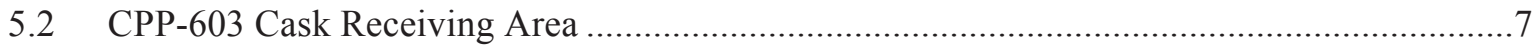

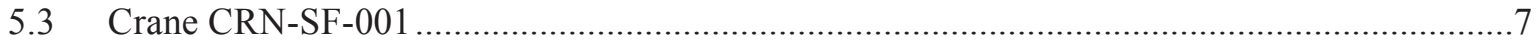

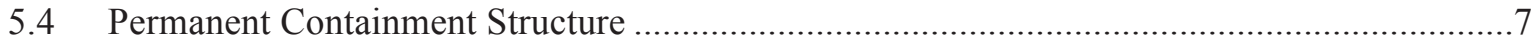

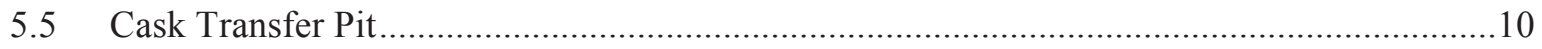

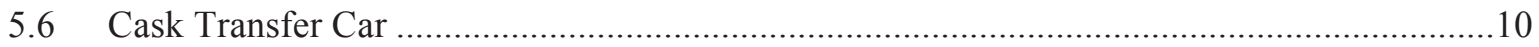

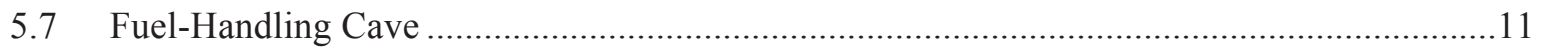

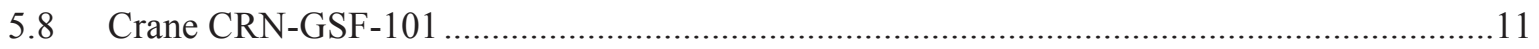

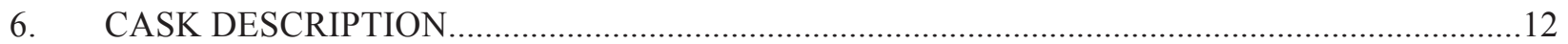

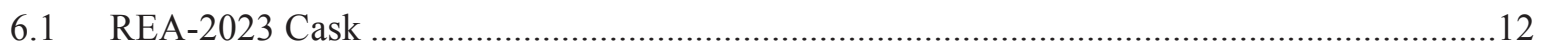

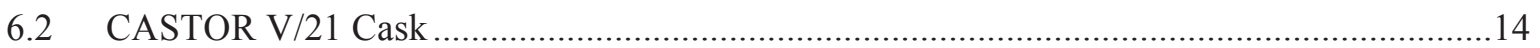

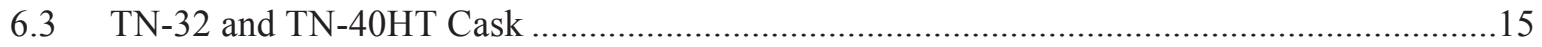

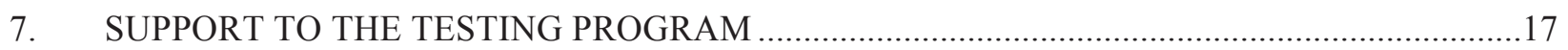

7.1 Fuel Transfer from CPP-603 to the Testing Facility .............................................................17 


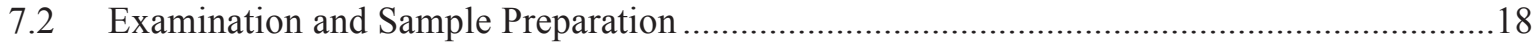

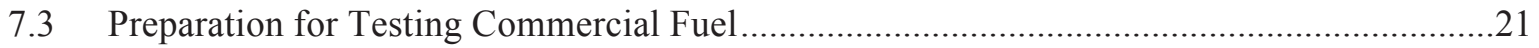

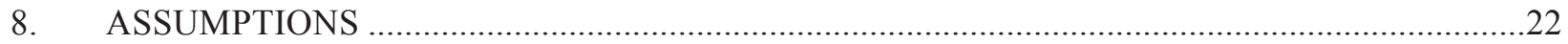

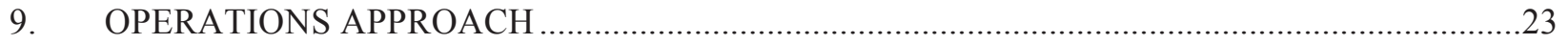

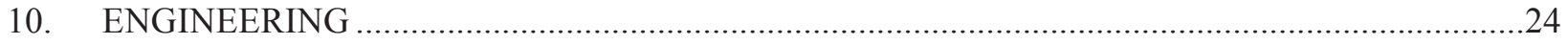

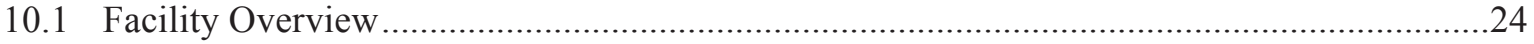

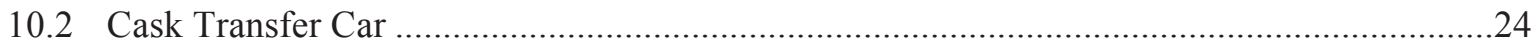

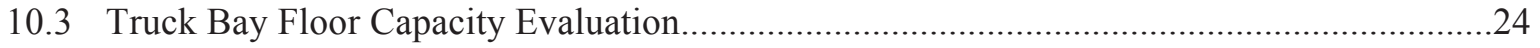

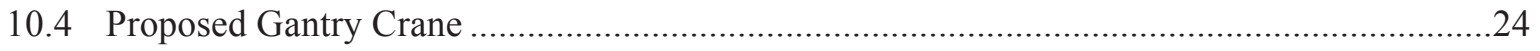

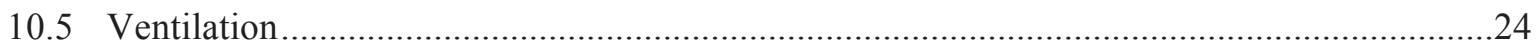

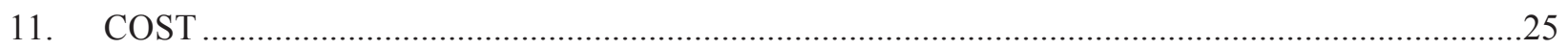

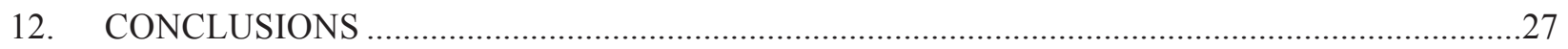

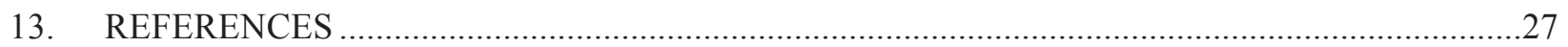

\section{FIGURES}

1. Aerial view of the Central Facilities Area, showing the rail yard that could be used to receive railcars carrying commercial dry storage casks ........................................................... 5

2. Aerial view of the Idaho Nuclear Technology and Engineering Center showing CPP-

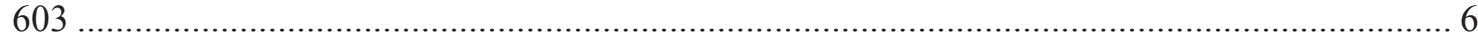

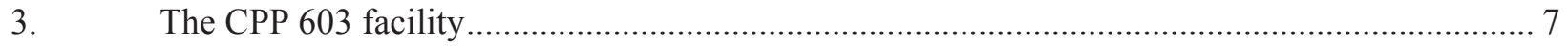

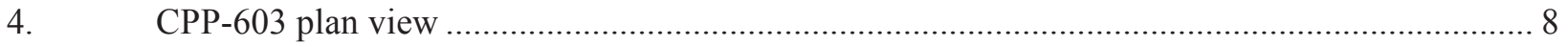

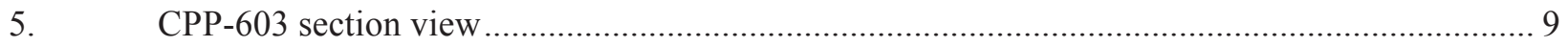

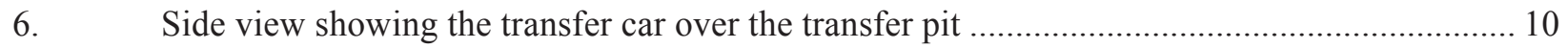

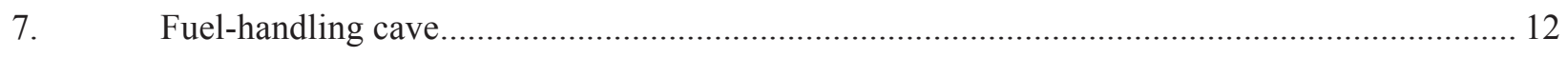

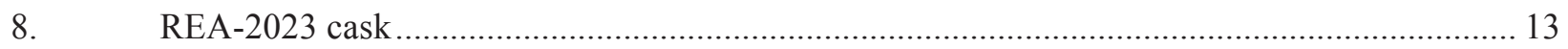

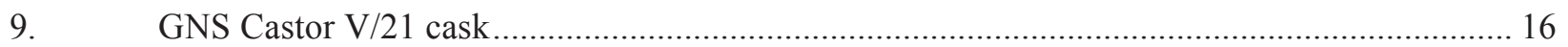

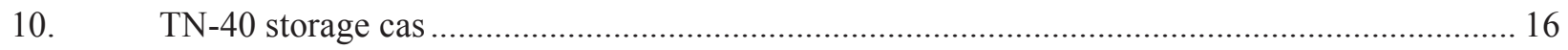


11. Hot Fuel Examination Facility plan view of the main floor, showing the locations of important fuel characterization stations

12. Possible layout of a gantry crane 25

\section{TABLES}

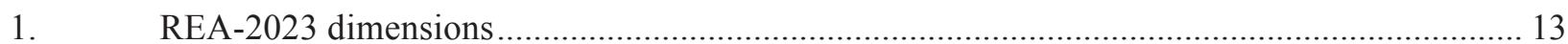

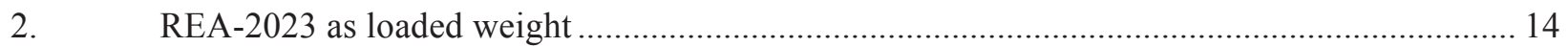

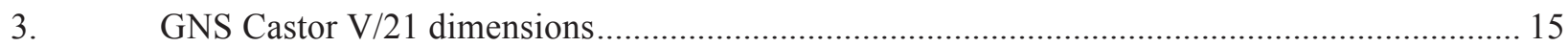

4. TransNuclear Inc. bolted-lid cask dimensions and specifications ........................................... 17 
This page intentionally left blank. 


\section{ACRONYMS}

$\begin{array}{ll}\text { BWR } & \text { boiling water reactor } \\ \text { CFA } & \text { Central Facilities Area } \\ \text { DOT } & \text { Department of Transportation } \\ \text { EDF } & \text { engineering design file } \\ \text { GNS } & \text { Gesellschaft für Nuklear Service } \\ \text { HFEF } & \text { Hot Fuels Examination Facility } \\ \text { INL } & \text { Idaho National Laboratory } \\ \text { INTEC } & \text { Idaho Nuclear Technology and Engineering Center (formerly ICPP) } \\ \text { MFC } & \text { Materials and Fuels Complex } \\ \text { NAC-LWT } & \text { NAC International, Inc. Legal Weight Truck } \\ \text { PCS } & \text { permanent containment structure } \\ \text { PWR } & \text { pressurized water reactor } \\ \text { REA } & \text { Ridihalgh, Eggers \& Associates, Inc. } \\ \text { TN } & \text { TransNuclear, Inc. } \\ \text { UFDC } & \text { used fuel disposition campaign } \\ \text { UNF } & \text { used nuclear fuel }\end{array}$


This page intentionally left blank. 


\section{Viability of Existing INL Facilities for Dry Storage Cask Handling}

\section{INTRODUCTION}

This report investigates the viability of an existing Idaho National Laboratory (INL) facility to support receipt and handling of used nuclear fuel storage casks and removal of fuel for examination. Formerly, INL used the large Test Area North Hot Shop (TAN-607) for performing this work; that facility was decommissioned and demolished in 2007. This investigation was performed to inform the Used Fuel Disposition Campaign (UFDC) of another INL facility built to handle nuclear fuel casks that could be used as a replacement for the Test Area North Hot Shop.

This report also evaluates the capability of INL's Hot Fuels Examination Facility (HFEF) to support used fuel rod characterization and sample preparation. The lengths of modern nuclear fuels are growing longer. HFEF was constructed in the 1970s and it is important to ensure the facility can accommodate these newer fuel designs. A brief discussion about how fuel rods and samples would be moved between INL facilities and to other laboratories is provided.

This report fulfills the M2 milestone, M2FT-13IN0802027, develop and issue "Long Term Used Nuclear Fuel Storage Viability Report," under Work Package Number FT-13IN080202.

\section{BACKGROUND}

The U.S. Department of Energy's Office of Nuclear Energy and Office of Fuel Cycle Technology established the UFDC to identify alternatives and conduct research and development related to storage, transportation, and disposal of used nuclear fuel (UNF) and high-level radioactive waste generated by existing and future nuclear fuel cycles. The storage and transportation activities within the UFDC are being developed to address issues regarding the extended storage of UNF and its necessary transportation. The near-term objectives of this storage and transportation task are to use a science-based, engineering-driven approach to develop the technical bases to support continued safe and secure storage of UNF for extended periods, subsequent retrieval, and transportation.

While both wet and dry storage have been shown to be safe options for storing UNF, a large focus of the program is on dry storage of commercial UNF at reactor locations or centralized locations. Because limited information is available on the properties of high burnup fuel (i.e., fuel exceeding 45 gigawattdays per metric ton of uranium) and because much of the fuel currently discharged from today's reactors exceeds this burnup threshold, a particular emphasis of this program is on high burnup fuels.

An extensive effort was made to identify the technology gaps in the Used Fuel Program related to storage and transportation. The report "Review of Used Nuclear Fuel Storage and Transportation Technical Gap Analysis," ${ }^{[1]}$ dated July 2012, identifies a high-priority gap, "Examine Fuel after Storage," as follows:

This item was expanded from "examine the fuel at INL" to the more general "examine fuel after storage," which was identified by a number of organizations and countries. The purpose of this gap was to obtain a second data point on low burnup fuel that has been in dry storage, but applies as well to high burnup fuel after it has been in storage for some period. While there is emphasis on the fuel and cladding, closing this gap includes examining the entire dry cask storage system (DCSS) after storage, including the fuel, cladding, assembly hardware, baskets, neutron poisons, canister/cask, overpack if applicable, and pad. This activity will provide data used in evaluating performance models of all SSCs [structures, systems, and components]. 
Commercial low burnup fuel stored at INL in the Castor V/21 storage cask was examined in 1999, and the data from that examination provided part of the current basis for extended licensing of existing storage casks.

The only fuel-handling method currently available to the commercial nuclear generating industry is to bring a cask back into a spent fuel pool for reopening. However, dry handling of the cask and fuel is important to avoid disturbing the properties of the cask, cladding, fuel, and related hardware that would occur if the materials were rewetted and rapidly cooled. Measuring, sampling, and testing the materials in a dry fuel-handling facility will improve the quality of the confirmatory data gathered. Further, handling the cask dry allows the cask to be resealed and the test continued without the potential of adverse and complicating effects associated with redrying and the accompanying temperature increases.

The purpose of this report is to describe the existing and easily achieved capabilities at INL to receive, handle, open, and extract fuel from a dry storage cask in a manner that will allow examination of the fuel to support confirmatory analyses needed to facilitate the continued storage of the fuel and to support the handling and transportation necessary for final disposition

The UFDC identified the following activities to advance the storage and licensing of high-burnup fuel:

- Evaluate the cost and schedule for the capital additions or improvements necessary to support a full-sized cask dry storage demonstration

- Recommend the preferred casks that should be used to perform the demonstration

- Integrate the work of participating national laboratories and private industry for fuel selection, loading, drying, and transportation

- Determine the preferred cask-handling solution from possible alternatives

- Coordinate the work of participating national laboratories to ensure the correct set of technical and functional requirements are met and to look at possible alternative commercial sites and strategies for implementation of a full-sized demonstration.

Elements of this viability report include identifying the scope of activities, schedule, and costs, and proposing the approach for opening casks dry and delivering samples to a laboratory for testing, in support of determining the preferred cask-handling solution from possible alternatives. A feasibility-level cost estimate and schedule are included. This scope of work only includes activities to complete this viability study. If handling of used nuclear fuel storage casks at this existing INL facility is desired, the project can be developed and implemented in time to support the UFDC's dry storage demonstration.

\section{SCOPE}

Establishing a capability that can handle used nuclear fuel dry storage casks and the fuel inside them will support a confirmatory dry storage demonstration. UNF casks currently are being handled in a dry condition at INL's CPP-603, Irradiated Fuel Storage Facility. ${ }^{[4]}$ Without significant facility modifications, CPP-603 can handle the type of casks anticipated for use in the dry storage demonstration program. Samples retrieved from the casks after opening can be shipped off-highway to INL's Materials and Fuels Complex (MFC). Alternatively, samples can be shipped to other testing facilities using Department of Transportation (DOT)-approved casks or drums.

The exact data needed from a demonstration, as well as methods to gather that data, are still being developed by the UFDC. At a minimum, a demonstration cask must be opened and a sampling of fuel assemblies must be removed to allow examination of both the fuel assemblies and cask interior. This report labels this capability as Case 1, Observation. This report primarily focuses on this case. 
Two additional cases also are evaluated in this report. These cases can be implemented if deemed necessary. Case 2, Non-Destructive Examination, would perform additional measurements and tests inside the CPP-603 fuel-handling cave. Case 3, Sampling for Destructive Examination, would enable a complete fuel examination campaign to be conducted. Case 3 includes removal of fuel rods and shipping them to MFC for a thorough examination using INL's existing post-irradiation examination capabilities. This case also enables the ability to provide samples to other laboratories and universities that support the UFDC.

\subsection{Dry Storage Casks}

The type of casks that need to be opened bound the scope of this report. A cross cutting need titled, "Examine Fuel in the Idaho National Laboratory Casks," ${ }^{[2]}$ is identified as being of high importance to the UFDC research and development mission. The description of the need is as follows:
It is recommended that the CASTOR V/21 cask, internals, and the underlying concrete pad at INL be re-examined. Likewise, it is recommended that the REA-2023 cask, which is known to have breached confinement, also be examined. The main drivers for opening and examining these casks and fuels are to obtain additional data to support the extended storage of low burnup fuel (with an additional 11 to 14 years of storage), and to determine the effect of confinement breach on internal structures, systems, and components.

As such, this report considers the Castor V/21 and REA-2023 casks within the scope of this evaluation.

A confirmatory dry storage demonstration of high-burnup fuel could utilize used fuels that are stored in both welded-lid and bolted-lid configurations. While the highest percentage of used fuel currently being generated by commercial utilities is being placed in welded-lid casks and canisters, use of welded lids for a demonstration is technically complicated. Removal of a welded storage cask lid is problematic, and resealing such a cask has never been done. Continued storage and periodic examination of a deheaded cask would be costly and technically challenging. Thus, for the purposes of this evaluation, only bolted-lid dry storage casks are considered. Although the long-term conditions in the cask could differ depending on whether the lid is welded or bolted, those differences can be addressed in the analysis of the data collected and are manageable in the context of the broader objectives of the UFDC.

Both boiling water reactor (BWR) and pressurized water reactor (PWR) high burnup UNF have been loaded into dry storage. PWR UNF is thought to be the limiting case from an extended storage performance perspective, because PWR high burnup fuel typically has thinner cladding and higher gas pressure, in addition to a higher burnup than BWR fuel.

In the United States, large bolted-lid storage casks primarily are limited to the TransNuclear, Inc. TN32 and TN-40 family of casks. These two casks serve as the basis for evaluation in this report. However, these evaluations are still relevant to other types of casks. For example, the TN-68 cask, which is licensed for BWR fuel, is of similar size and weight to the PWR casks. Thus, the analyses of this report can be extended to other cask types if they become prevalent or desired in the future.

\subsection{Case 1, Observation}

Case 1, Observation, is limited to opening the casks and performing visual inspections of fuel and cask components. Cask movement to the fuel-handling cave will be accomplished using a portable gantry crane in CPP-603, with enough lift capacity to handle the TN-32 and TN-40HT casks. The existing bridge crane can handle the REA-2023 and the Castor V/21 casks, but it cannot lift the heavier casks (see Section 6 for cask details). The existing bridge crane will be available to help set up the gantry crane and support the minor facility modifications required to support the observations. The minor facility modifications, described more thoroughly in Section 10, include modifying the permanent containment 
structure (PCS), fabrication and installation of cask-specific transfer car adapters, and fabrication of lifting fixtures for various cask and fuel components. The REA-2023 and Castor V/21 casks currently are stored on the CPP-2707 cask storage pad near CPP-603; the TN-32 and TN-40HT casks can be transferred to CPP-603 from a rail line that currently exists near CPP-603. Included in the scope are cask and fuel element handling and observation.

The TN-32 and TN-40HT casks also can be transferred from the existing rail line at INL's Central Facilities Area (CFA) using a mobile boom crane to lift the cask off the rail car and place it on a truck/trailer to haul it to CPP-603. The cask impact limiters will be removed and the cask placed on the transporter in a vertical position. The truck/trailer can drive into CPP-603 through any of four truck bay doors.

Installation of the gantry crane in CPP-603 will be subcontracted to a company experienced in such operations. The subcontractor will set up and load-test the posts, rails, and crane that can lift the cask and move along the rails, bringing the cask from the delivery truck/trailer to the transfer car. The gantry will be demobilized after observations are complete, the cask will be moved to the truck/trailer, and the facility will be restored to its current operational capacity. Section 10.4 describes the gantry crane.

Once loaded on the transfer car, the interior atmosphere of the cask would be sampled for analysis. The cask outer lid and bolts for the shield lid will be removed. The cask will be moved into the fuelhandling cave, where the cask shield lid will be removed. At least one fuel assembly will be lifted out of the cask and observations will be conducted on the condition of the fuel and the interior of the cask. Observations will include collection of photographic records. Case 1 will end with replacing the fuel assembly(ies) in the cask, adding or repairing in-cask instruments or instrument packages, restoring the cask atmosphere, and returning the cask to storage, either at INL or the generating utility via rail.

The cask internal atmosphere would be reestablished to match the composition of the gas sample taken just prior to opening. Water vapor, oxygen, hydrogen, and inert fill gas (e.g., helium or nitrogen) would be mixed in proportions needed to match that initial composition. That gas could be procured from a qualified vendor or could be mixed in-house; however, purchasing a certified mixed gas from a vendor is often far less costly than manually mixing gases (particularly when larger quantities are needed). Fission gases would not be mixed in the replenishment gas; that way, any pin failures that might occur after the cask is resealed could be detected. The cask would be sealed, purged with inert fill gas to remove air, and then purged again with the replenishment gas to establish the atmosphere.

\subsection{Case 2, Non-Destructive Examination}

Once the cask is moved into the fuel-handling cave, observations conducted under Case 2 could be augmented with metrology, cladding condition measurements, temperature readings, and gamma spectroscopy. Metrology will include measurements of the diameter of rods at various locations, length, and bowing. Cladding condition could be examined with eddy current or ultrasonic equipment. Temperature readings at or near the surface of the cladding at various locations could give indications of temperature distribution. Gamma spectroscopy would provide information on fuel burnup uniformity and fission product distribution.

All of these observations could be accomplished with varying degrees of retooling in the fuel-handling cave and incremental increases in the cost and schedule of the project. The cost and schedule impacts of Case 2 are not included in this report. It is important to note that non-destructive examinations will be easier to conduct in a dry environment and likely will yield the best results when compared to attempting to perform the operation underwater in a spent fuel storage pool.

\subsection{Case 3, Sampling for Destructive Examination}

In addition to the non-destructive examination described in Section 3.3, rods could be removed from the fuel assemblies and sent to HFEF at MFC for characterization and testing. The Idaho Nuclear 
Technology and Engineering Center (INTEC) and MFC are linked by a haul road that allows shipping materials, without the need to travel over public highways, including possible closure of the highways. HFEF is the only facility in the U.S. Department of Energy complex that can accommodate full PWR and BWR fuel assemblies. The facility is purpose-built for fuel post-irradiation examinations and is supported by other research facilities at MFC that provide services such as advanced microscopy, mechanical properties testing, and analytical chemistry. The cost of shipping samples from CPP-603 to HFEF is included in this report.

\section{CENTRAL FACILITY AREA RAIL YARD}

The CFA rail yard (see Figure 1) is located less than 5 miles south of INTEC (formerly the Idaho Chemical Processing Plant) where the CPP-603 facility is located. This area was selected for unloading a dry storage cask from a rail car for several reasons. Although the rail goes to the CPP-603 facility, maintenance needs to be performed on the rail line that extends from the switch (connecting to the main north-south line running through the INL site) to the facility. While a cask can be unloaded from a rail car at the CPP-603 facility, it requires additional security controls due to working inside the INTEC fence than if this work is done at the CFA rail yard; therefore, the cost would be lower. Additionally, if a demonstration is to be continued after the initial inspection, then the cask needs to be moved from the facility to the CPP-2707 cask storage pad. There is no rail access to that pad and a trailer or other caskhandling machine must be used. If the Castor V/21 and/or REA-2023 casks are to be opened and inspected, a trailer or cask-handling machine also must move these casks. Because only a few casks (three or four) would be moved infrequently (once every 5 to 10 years or longer), it was determined that investing in rail repair and maintenance was less desirable than renting a heavy haul trailer for those few moves.

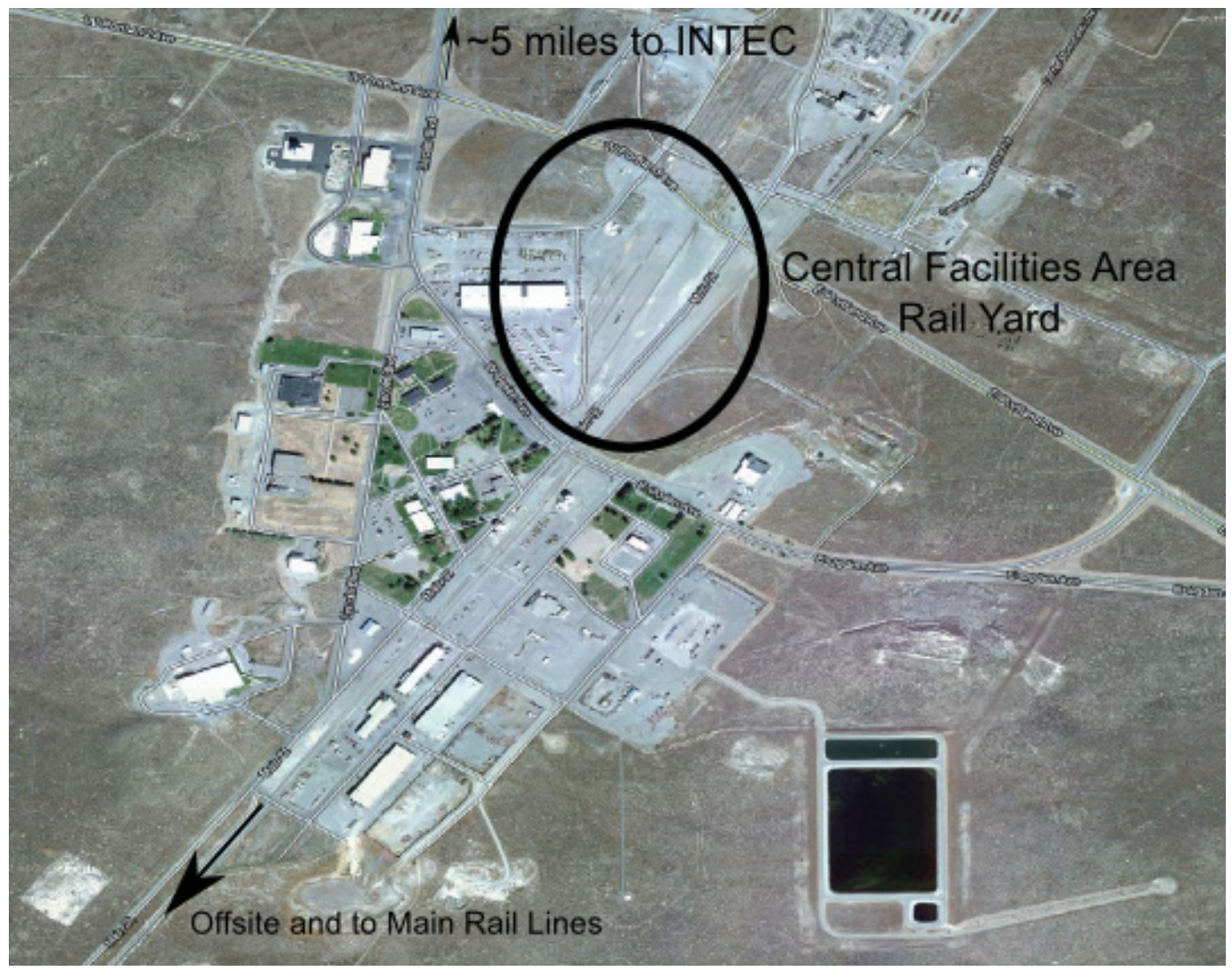

Figure 1. Aerial view of the Central Facilities Area, showing the rail yard that could be used to receive railcars carrying commercial dry storage casks. 


\section{CPP-603 DESCRIPTION}

\subsection{CPP-603, Irradiated Fuel Storage Facility}

The INTEC Irradiated Fuel Storage Facility's dry storage capability was built as an addition to the CPP-603 basin storage facility (see Figure 2). The facility addition was constructed in 1974 for the dry storage of irradiated graphite fuel from the Ft. St. Vrain high-temperature gas-cooled reactor. The CPP603 water basins have been decommissioned and remediated since then.

CPP-603 (see Figure 3) is a Hazard Category 2 nuclear facility designed for interim storage of irradiated fuel. CPP-603 also houses the operations and support staff needed for the facility's daily operation. The fuel storage area and fuel-handling cave were analyzed in 1996 and determined to meet current seismic criteria. The facility design depends on forced ventilation to ensure decay heat removal. The fuel storage area and the fuel-handling cave are served by the same ventilation system. The original, roof-mounted, ventilation system blowers, high-efficiency particulate air filtration, and stack were replaced in 2004 and relocated to grade level to ease maintenance.

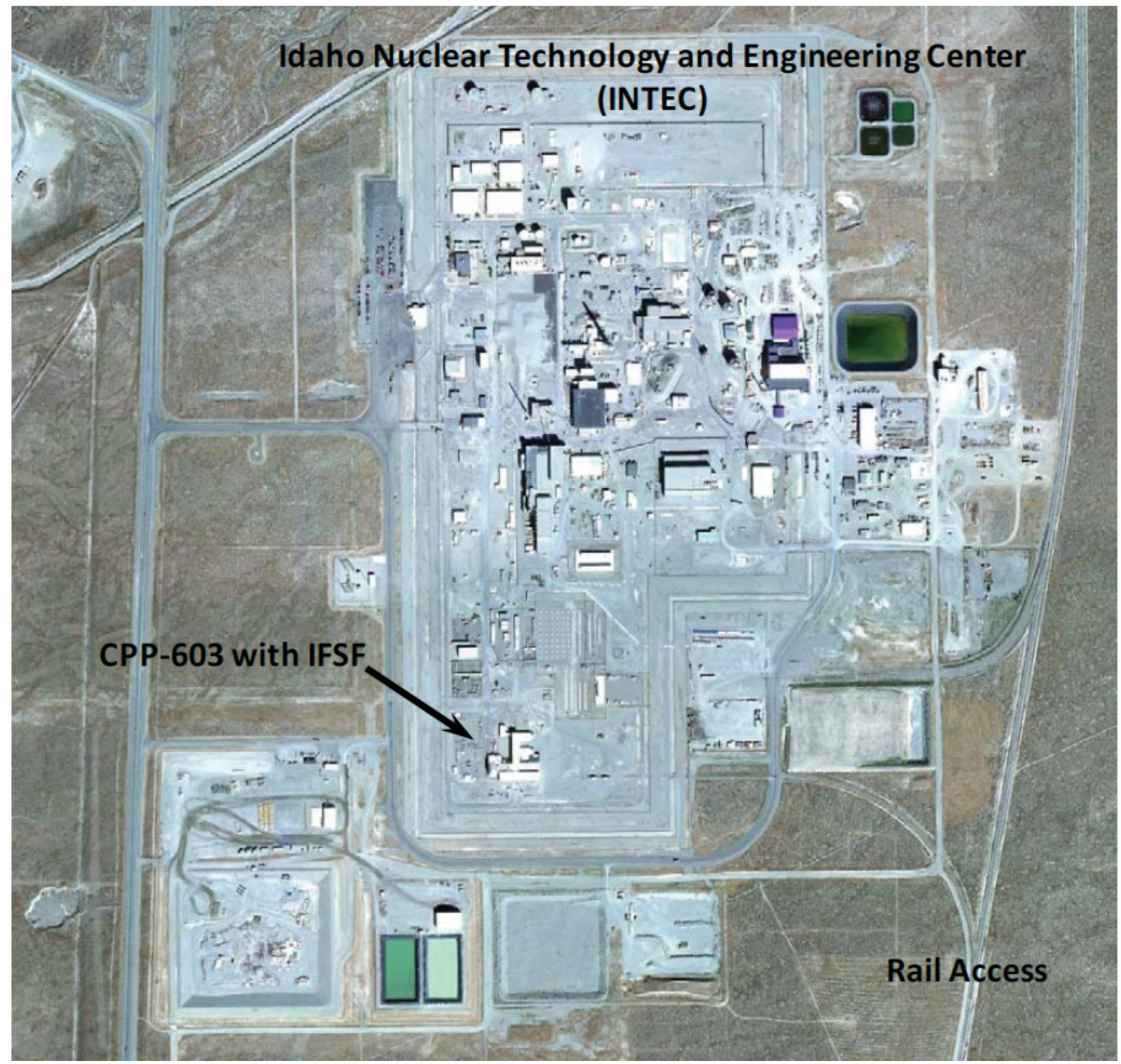

Figure 2. Aerial view of the Idaho Nuclear Technology and Engineering Center showing CPP-603. 


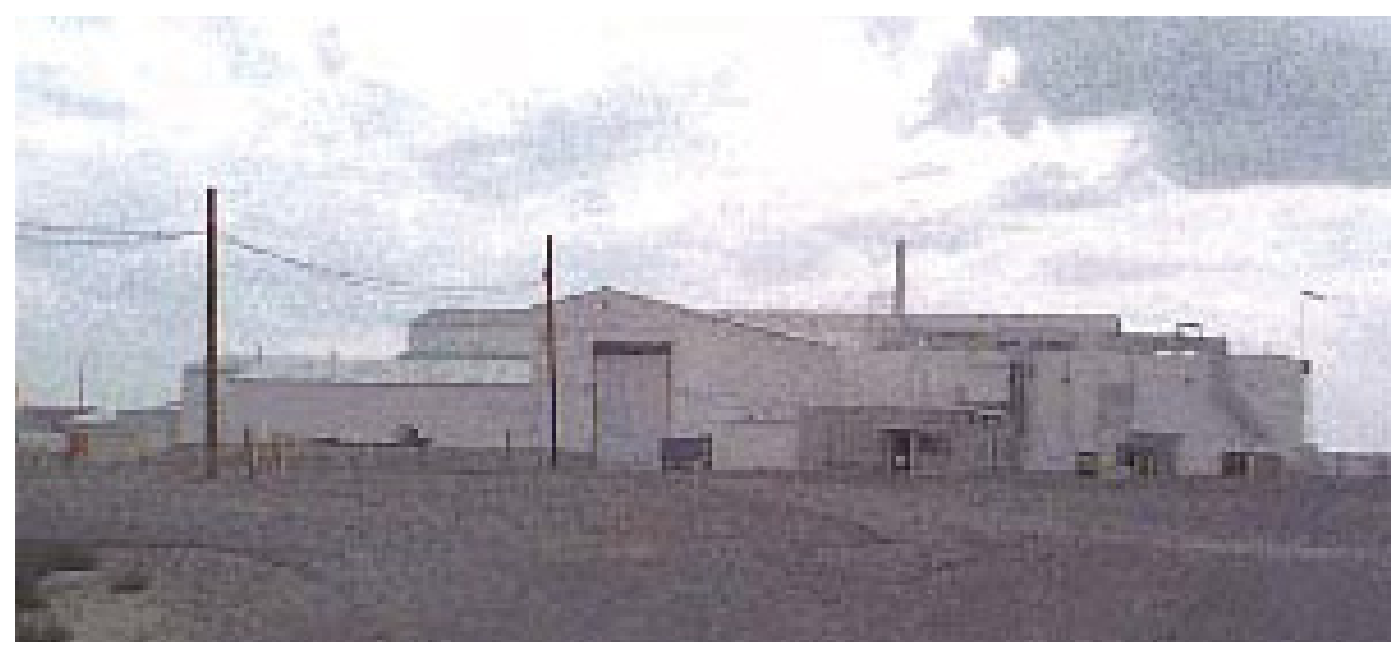

Figure 3. The CPP 603 facility.

\subsection{CPP-603 Cask Receiving Area}

The cask receiving area contains a truck ramp that slopes down from west to east, lying along the south wall of the storage area and fuel-handling cave. This configuration allows fuel-cask-bearing trucks to obtain a lower elevation for unloading and loading of casks. CPP-603 also includes both a north-south and an east-west truck bay with external doors. Originally, the east-west bay also included rail access. The overall plan of the facility is shown in Figure 4 and Figure 5.

\subsection{Crane CRN-SF-001}

An overhead crane, CRN-SF-001 (see Figure 4), services the cask receiving area and travels the full length of the truck bay. The crane was designed for a 75-ton capacity, but currently has a rated capacity of 60 tons when lifting from both beam-end lifting fixtures and 40 tons when lifting from the crane hook. Therefore, this crane will be inadequate to handle the loads needed for commercial fuel casks, but will be useful for other lifting as needed (e.g., movement of cask cradles, fixtures, and lids).

\subsection{Permanent Containment Structure}

The PCS (see Figure 4) is a stainless steel sheet and angle iron structure that encloses the portion of the transfer car pit located outside the fuel-handling cave. The PCS confines any possible contamination that could be transferred out of the fuel-handling cave during operational use.

During use, the PCS has top and side panels that can be opened to provide crane access and allow transfer of a cask (or other equipment) to and from the cask transfer car. Walk-through doors on the east side of the PCS are provided for personnel access. The doors to the PCS are normally closed when the PCS is not being accessed. The PCS has a separate, manually controlled, high-efficiency particulate airfiltered exhaust system. Lead blankets may be installed inside the wall of the PCS to provide additional shielding to personnel (in accordance with the Radiation Protection Program) when moving the cask transfer car while fuel is present in the fuel-handling cave. Inside the PCS, a cask can be surveyed, vented, and decontaminated, if necessary, before exposing it to the clean environment of the cask receiving area.

To date, the inside of the PCS has been kept free of contamination. This allows the panels that provide crane access to be opened during crane operations. 


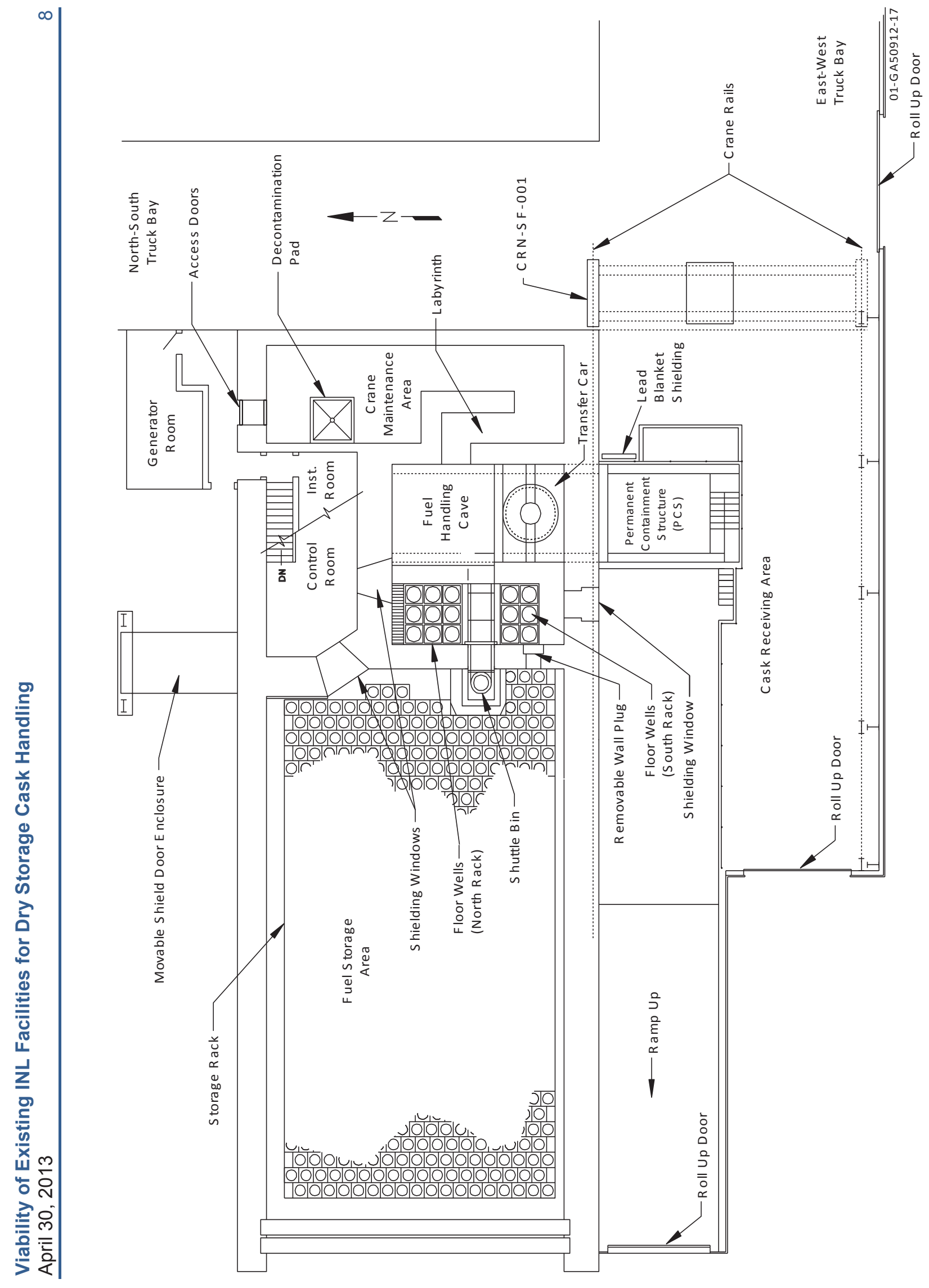

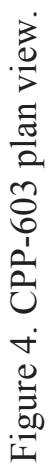



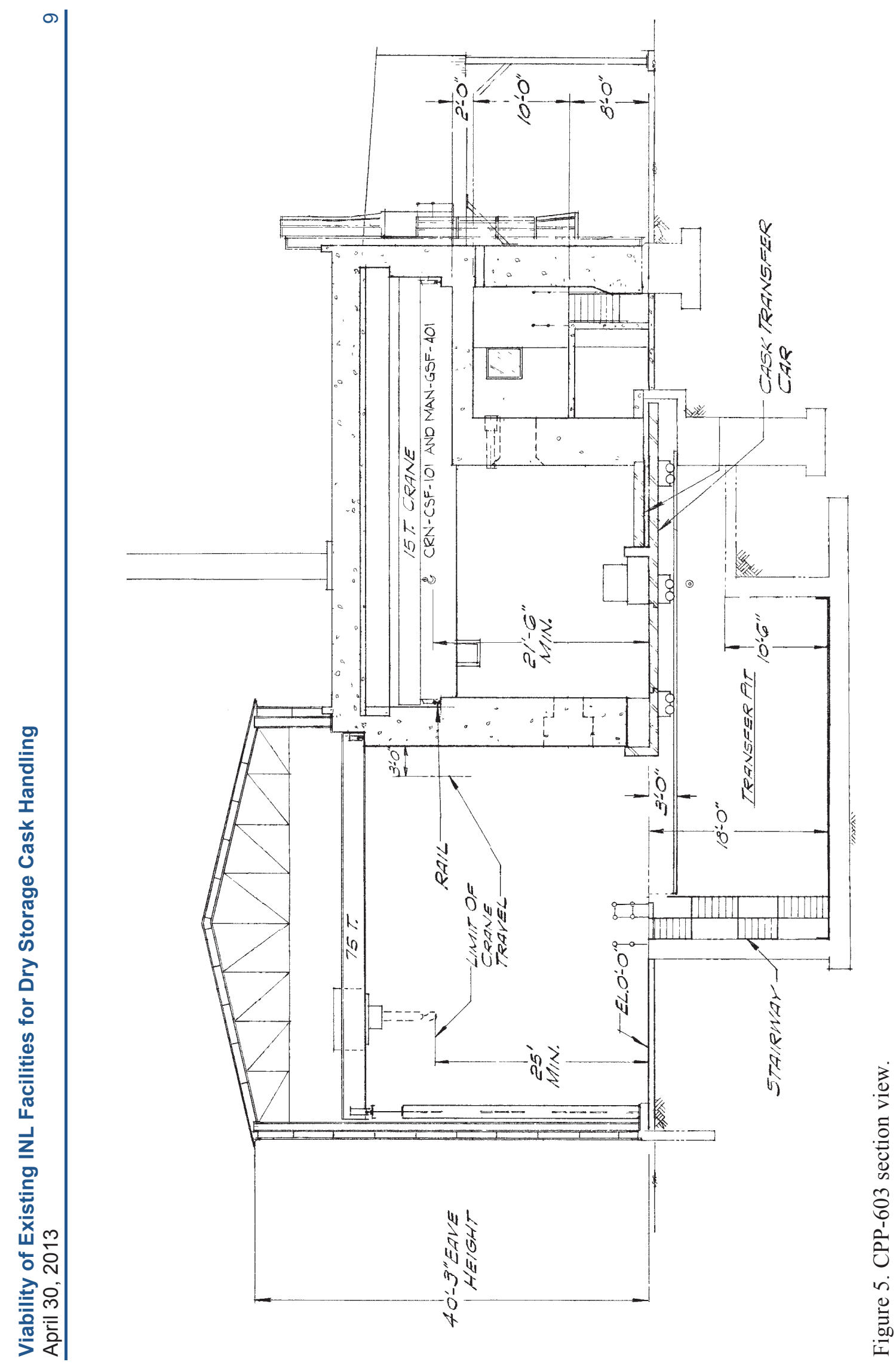


\subsection{Cask Transfer Pit}

The cask transfer pit, which contains the cask transfer car, is approximately 10 -ft wide, $44-\mathrm{ft}$ long, and 18-ft deep (see Figure 4 and Figure 5). The pit extends under the south wall of the fuel-handling cave, with approximately one-half of the pit located in the cask receiving area and the other half in the fuel-handling cave. This pit, along with the cask transfer car, provides radiation shielding during transfer of fuel casks between these areas. The east half of the fuel-handling cave floor is occupied by the 18 -ftdeep cask transfer pit that contains the cask transfer car and its associated drive mechanism. A 1-ft-thick steel plate covers the north third of the cask transfer pit to provide shielding between the cave and the pit. The plate also provides a place to set heavy equipment, such as cask lids. When the cask transfer car is in the PCS, the top plate of the cask transfer car provides a continuous floor. When the cask transfer car is in the fuel-handling cave, the top plate of the cask transfer car becomes the floor of the cave.

\subsection{Cask Transfer Car}

The cask transfer car, in combination with its associated transfer equipment (i.e., inserts, adapters, sliding saddles, and transfer devices), is used to support the fuel shipping casks and transfer them between the cask receiving area and fuel-handling cave (see Figure 6). When positioned in the cask receiving area, the cask transfer car isolates the fuel-handling cave from the cask transfer pit. This isolation maintains ventilation control and provides radiation shielding between the fuel-handling cave and the cask receiving area.

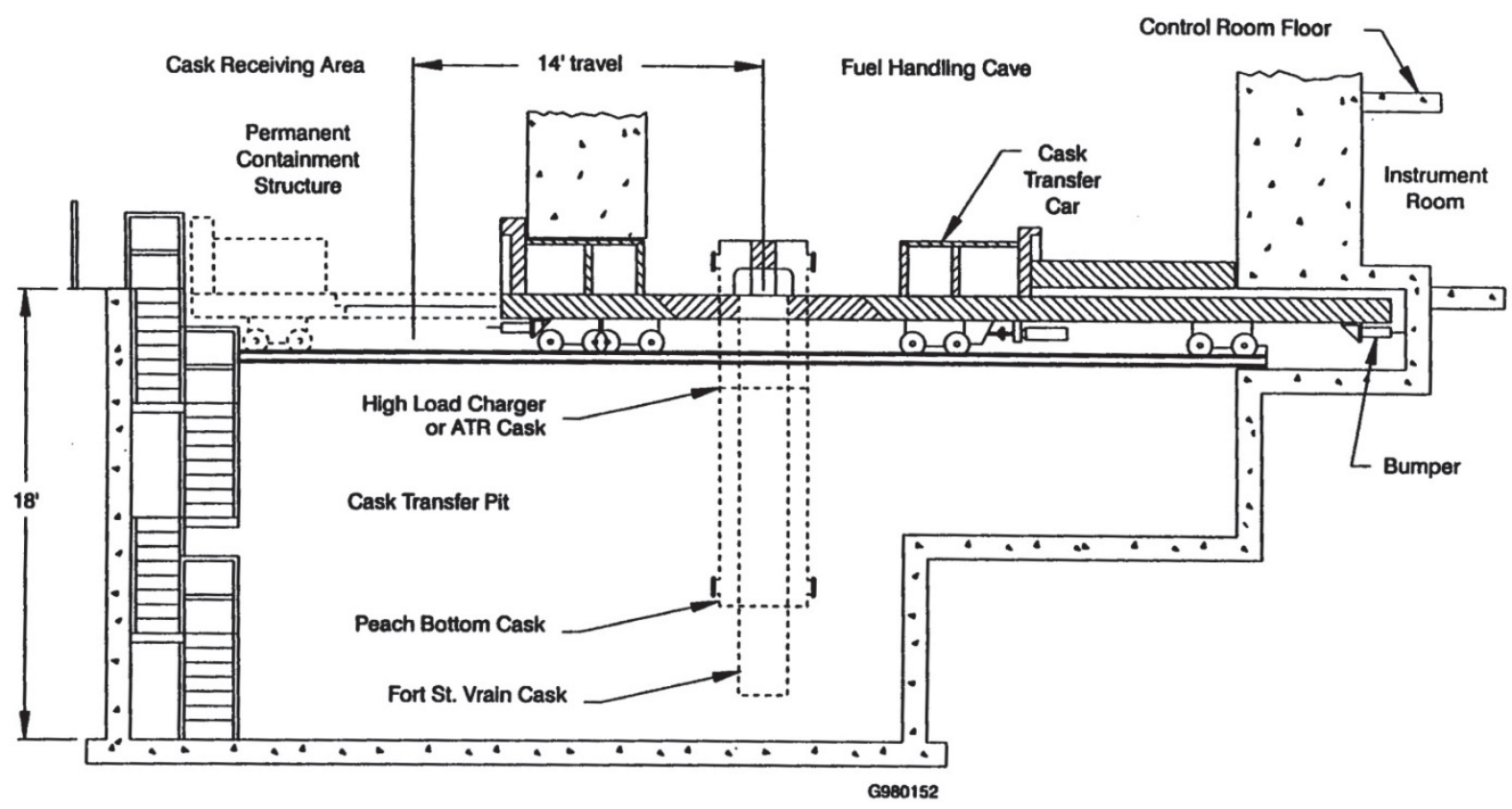

Figure 6. Side view showing the transfer car over the transfer pit.

The transfer car is 12 -ft wide by 35 -ft long, has a 12 -in.-thick steel deck, and weighs $306,000 \mathrm{lb}$ without its load. The car is mounted on 12 railroad wheels that travel on two steel rails located in the cask transfer pit. The car has an overall travel distance of $14 \mathrm{ft}$. The car originally was designed to a 278 ton capacity, but was never tested to that capacity. Thus, the transfer car will require load verification prior to use with casks other than those for which it currently is approved.

The transfer car was fabricated with an 8-ft-7-in. diameter opening located approximately in the center of the car to accommodate various spent nuclear fuel cask configurations. Inserts are designed to adapt the opening of the transfer car to carry specific casks. When a shipping cask, charger, or other 
container arrives at the storage facility, the proper cask transfer car insert and, in some cases, an additional adapter plate or device, are placed in the cask transfer car opening to support the cask in the cask transfer car.

The cask transfer car's electromechanical drive system is controlled from either the control room or the cask receiving area. Each control station includes two start buttons (one to start movement into the cave and the other to start movement out of the cave), a stop button, and position-indicating lights. In addition, the control room station includes a master lockout key switch that interrupts all power to the car control circuits. Interlocks prevent energizing the drive motor forward and reverse at the same time, and limit switches prevent over-travel of the car. The cask transfer car is supplied with normal and standby power.

The cask transfer car is constructed with two shielding boxes. One shielding box is located at the south end of the cask transfer car deck and one is located at the middle. The shielding boxes are constructed of three vertical steel plates (sometimes called baffle plates) housed in 1-in.-thick steel plate. The shielding boxes are 12 -ft wide by 26 -in. tall and 69 -in. thick. When the cask transfer car is fully positioned in either area, a shielding box completely closes the hole in the shielding wall, providing a minimum of $12 \mathrm{in.} \mathrm{of} \mathrm{steel} \mathrm{for} \mathrm{radiation} \mathrm{shielding.} \mathrm{The} \mathrm{shielding} \mathrm{boxes} \mathrm{and} \mathrm{the} \mathrm{sides} \mathrm{of} \mathrm{the} \mathrm{cask} \mathrm{transfer}$ car are provided with stainless-steel wipers that assist in ventilation control.

\subsection{Fuel-Handling Cave}

The fuel-handling cave (see Figure 4 and Figure 7) is used to receive fissile and radioactive materials from the cask receiving area on the cask transfer car, transfer materials between shipping casks and storage containers, prepare materials for storage, and dry fuels in the fuel conditioning station. Fuel also is examined in the fuel-handling cave, using the in-cave examination system equipment that is remotely operated from the control room. To perform these functions, the fuel-handling cave is equipped with a crane (CRN-GSF-101) and an electromechanical manipulator with a hoist (CRN-GSF-401), mounted on a common trolley and bridge; wall-mounted manipulators; two shielding windows; video camera system; floor wells for temporarily storing fuel storage canisters; and a shuttle bin for transferring canisters between the fuel-handling cave and the fuel storage area.

\subsection{Crane CRN-GSF-101}

Crane CRN-GSF-101 is a double girder bridge, 15-ton, remotely operated, overhead bridge crane that currently is rated for 10 tons. The crane is used to move fuel storage canisters, remove and replace cask lids, load and unload fuel from casks, transfer fuel, and move equipment in the fuel-handling cave. The maximum hook height of the crane is approximately $21 \mathrm{ft} 6 \mathrm{in}$. (see Figure 5) above the top of the cask transfer car. The crane has sufficient bridge and trolley travel to permit access to all areas of the fuel-handling cave.

The crane hoist is provided with an electrical solenoid and a mechanical brake; this ensures that in the event of power loss, the crane hoist locks up and the load is not dropped. The crane hook is designed with a motorized closure latch or lock that ensures that a load will not be dropped from the hook if the lifting fixture and hook are properly engaged and the lock is closed. 


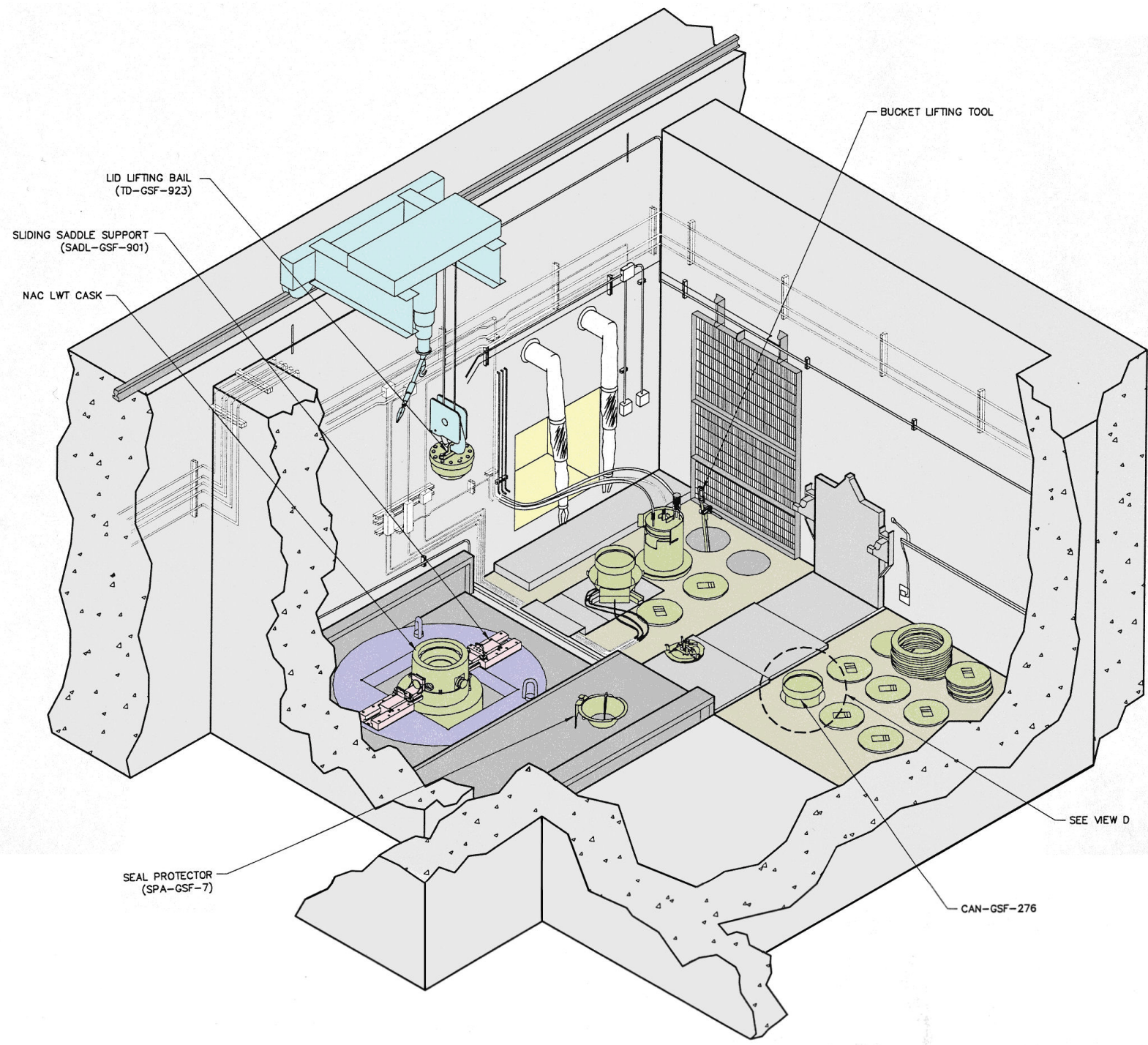

Figure 7. Fuel-handling cave.

\section{CASK DESCRIPTION}

This report evaluates the handling and opening of four dry storage casks. The logic for these casks is detailed in Section 3.1. It is important to note that any bolted-lid cask that is similar in size and shape can be accommodated, because the cost to develop fixtures and ancillary equipment would be similar to the cases considered in this report. The four casks evaluated in this report are the REA-2023, Castor V/21, TN-32, and TN-40 HT. The following subsections describe each of these casks.

\subsection{REA-2023 Cask}

The Ridihalgh, Eggers, and Associates, Inc. REA-2023 cask is a cylindrical double containment design consisting of an outer shell, an inner containment vessel, lead gamma shielding, and a neutron moderator. The REA-2023 cask is shown in Figure 8. The cask is approximately 16 - $\mathrm{ft} \mathrm{high,} 8$ - $\mathrm{ft}$ in diameter, and weighs approximately 96 tons fully loaded and 76.91 tons currently loaded. Table 1 contains the REA-2023 design features and Table 2 contains the REA-2023 cask loaded weight. The REA-2023 cask was originally designed for both horizontal and vertical storage; however, with changes 
to the fuel basket design discussed in the following paragraphs, storage is limited to only the vertical configuration.

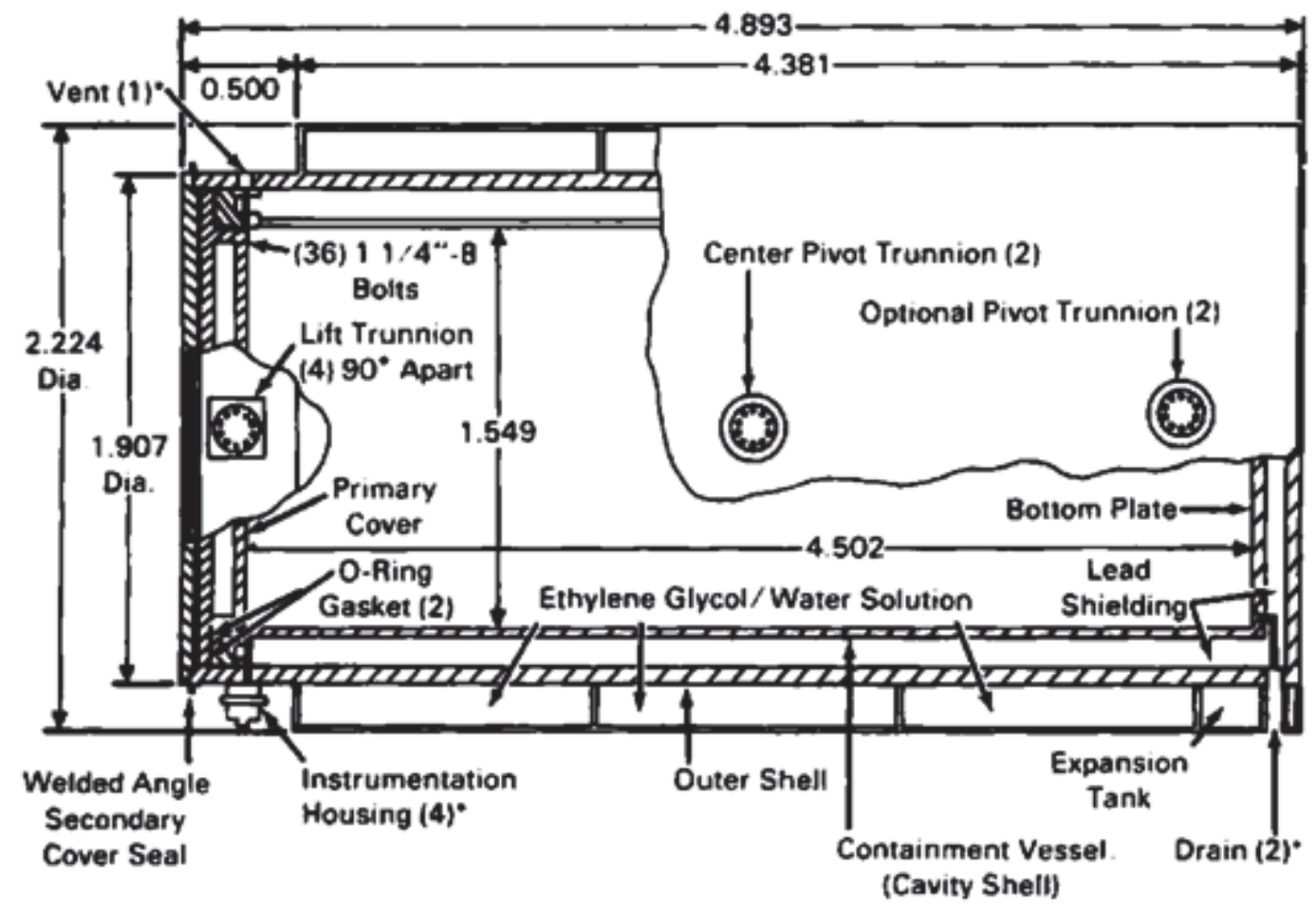

\section{Dimensions are in Meters}

- Aotated From True Position

Figure 8. REA-2023 cask.

Table 1. REA-2023 dimensions.

\begin{tabular}{lc}
\hline \multicolumn{1}{c}{ Dimension } & Length \\
\hline Cask overall external length & $192.62 \mathrm{in.}$ \\
Overall external diameter & $87.56 \mathrm{in.}$ \\
Inner stainless-steel shell thickness & $0.75 \mathrm{in.}$ \\
Lead shielding thickness & $4.25 \mathrm{in.}$ \\
Outer stainless-steel shell thickness & $2.0 \mathrm{in.}$ \\
Bottom thickness & $7.0 \mathrm{in.}$ \\
Cavity length & $177.25 \mathrm{in}$. \\
Cavity diameter & $61.00 \mathrm{in}$. \\
Design pressure & 50 psig maximum \\
Design internal heat source & $20.8 \mathrm{~kW}$ total \\
Weight (empty) & 64.23 tons \\
Weight (fully loaded) & 96 tons \\
\hline
\end{tabular}


Table 2. REA-2023 as loaded weight.

\begin{tabular}{|c|c|}
\hline Items & Weight (lb) \\
\hline REA-2023 cask empty & $128,460.00$ \\
\hline REA-2023 insert & $4,700.00$ \\
\hline Overpack Coffin A & $1,531.42$ \\
\hline Overpack Coffin B & $1,446.75$ \\
\hline Overpack Coffin C & $2,233.09$ \\
\hline Overpack Coffin D & $1,359.52$ \\
\hline Overpack Coffin H & $1,250.42$ \\
\hline Overpack Coffin J & $3,057.16$ \\
\hline Overpack Coffin K & $3,032.26$ \\
\hline Encapsulation Basket 1 & 800.00 \\
\hline Encapsulation Basket 2 & 800.00 \\
\hline Encapsulation Basket 3 & 800.00 \\
\hline Surry basket & 510.00 \\
\hline Loss-of-fluid test FP-1 canister & 950.00 \\
\hline 15 loss-of-fluid test FP-2 canister & $2,880.00$ \\
\hline Total & $153,810.62$ \\
\hline Total in tons & 76.91 \\
\hline
\end{tabular}

The majority of the material in the REA-2023 cask is damaged fuel and post-irradiation examination specimens from the loss-of-fluid test experimental reactor, stored in baskets, canisters, and "coffins."

A single Surry fuel storage basket that holds nine Surry fuel rods is stored in the REA-2023 cask. The basket dimensions are 6.6 in. x 7.6 in. x 172 in. long. The Surry fuel storage basket, when loaded with nine fuel rods, weighs $510 \mathrm{lb}$. The rods, when placed in the basket, extend a minimum of $1 \mathrm{in}$. above the top of the storage basket. This extension allows the rods to be removed from the basket. Dimensionally, the REA-2023 cask can be placed into the CPP-603 fuel-handling cave with enough head room in the cave for the Surry basket to be removed from the cask.

Engineering Design File (EDF)-9258, "Conceptual Structural Analysis for Crane Upgrade Capacity of CPP-603 East-West Truck Bay,"[3] concludes that the facility (as currently constructed) can handle a crane capacity of up to 85 tons without major building modifications. With the installation of an 85 -ton crane, the REA-2023 cask could be lifted and placed into the transfer car.

Another option would be to use a commercial hydraulic gantry system to lift the REA-2023 cask in CPP-603. The commercial, dry storage, demonstration casks was originally located at Test Area North and included the Castor V/21, MC-10, REA-2023, TN-24P, and VSC-17 designs. In 2003, the casks were moved 18 miles to INTEC. To perform this move, a temporary hydraulic gantry system, with the capacity to lift up to 110 tons, was used to place the casks on a heavy haul trailer for transport to the CPP-2027 cask storage pad. A complementary gantry system was used to remove the casks from the transport and place them on the pad.

\subsection{CASTOR V/21 Cask}

The Gesellschaft für Nuklear Service (GNS) Castor V/21 cask is a thick-walled, ductile-iron cylinder approximately $7.87 \mathrm{ft}$ in diameter and weighs approximately 108 tons fully loaded. The cask has a cylindrical cavity that holds a fuel basket designed to accommodate up to 21 PWR spent nuclear fuel 
assemblies. As shown in Table 3, the cask cavity is 5-ft wide and 13.78-ft long, with sidewalls measuring 1.3-ft thick. The fuel basket is made of borated ( $1 \mathrm{wt} \%$ boron) stainless-steel plates. The basket plates are approximately 0.20 -in., 0.39 -in., or 0.79 -in. thick, depending on the location. The thicker plates are in the center of the cask to reduce neutron interaction between the storage positions. Fuel assemblies are physically separated and maintained at specified separation distances by the fuel basket with nominally 8.7-in.-square storage positions.

Table 3. GNS Castor V/21 dimensions.

\begin{tabular}{lc}
\hline \multicolumn{1}{c}{ Dimension } & Length \\
\hline Cask overall external length & $192 \mathrm{in.}$ \\
Overall external diameter & $95 \mathrm{in.}$ \\
Wall thickness & $15 \mathrm{in.}$ \\
Cavity length & $162 \mathrm{in.}$ \\
Cavity diameter & $65.00 \mathrm{in}$. \\
Design pressure & $50 \mathrm{psig}$ maximum \\
Design internal heat source & $20.8 \mathrm{~kW}$ total \\
Weight (empty) & 93 tons ( 84 tonnes) \\
Weight (fully loaded) & 108 tons (98 tonnes) \\
\hline
\end{tabular}

The internal heat transfer medium of the cask is an inert gas (helium or nitrogen). The ductile-iron wall of the cask includes sections of neutron-moderating material that provide shielding for gamma and neutron radiation. Obtained from onsite radiation survey data for the Castor V/21 cask, the maximum dose rate is approximately $11 \mathrm{mrem} /$ hour. Gas purge and sampling functions are accommodated via a valve in the primary shield cover. The cover system is fitted with a leak-testing device and has a multiple seal consisting of O-rings.

The GNS Castor V/21 cask was designed and analyzed to withstand a 5-ft drop on its bottom edge or side without loss of integrity or loss of separation of fuel within fuel basket ports. The GNS Castor V/21 cask resists tipping from the vertical position for wind speeds up to $360 \mathrm{mph}$ and seismic horizontal accelerations of up to $0.5 \mathrm{~g}$. Features of the GNS Castor V/21 cask and closure system are shown in Figure 9. The main components of the GNS Castor V/21 cask are described in a topical safety analysis report.

\subsection{TN-32 and TN-40HT Cask}

The TransNuclear TN-24P, TN-40, and TN-32 designs are metal storage casks designed to store 24 PWR, 40 PWR, and 32 PWR spent nuclear fuel assemblies, respectively. The TN-24P cask received a Certificate of Compliance (\# 72-1005) from the Nuclear Regulatory Commission for storage of PWR spent nuclear fuel. The TN-40 cask design was approved as part of the safety analysis report for the Prairie Island ISFSI (Docket 72-10). The TN-40HT cask currently is under review by the Nuclear Regulatory Commission as part of a license amendment for the Prairie Island ISFSI. The Nuclear Regulatory Commission approved the TN-32 cask design for storage (Certificate of Compliance \# 72-1021) in April 2000.

As shown in Figure 10, the TN designs have a multiple-containment barrier system consisting of a primary lid, a neutron shield, and a protective cover. The primary lid is the innermost barrier with a double metallic O-ring gasket. Pressure transducers (three for redundancy) provide pressure measurement for leak-testing capability. The neutron shield is a polyethylene disc attached to the primary lid. The protective cover includes an elastomer O-ring seal and is bolted to the cask, providing weather protection. 


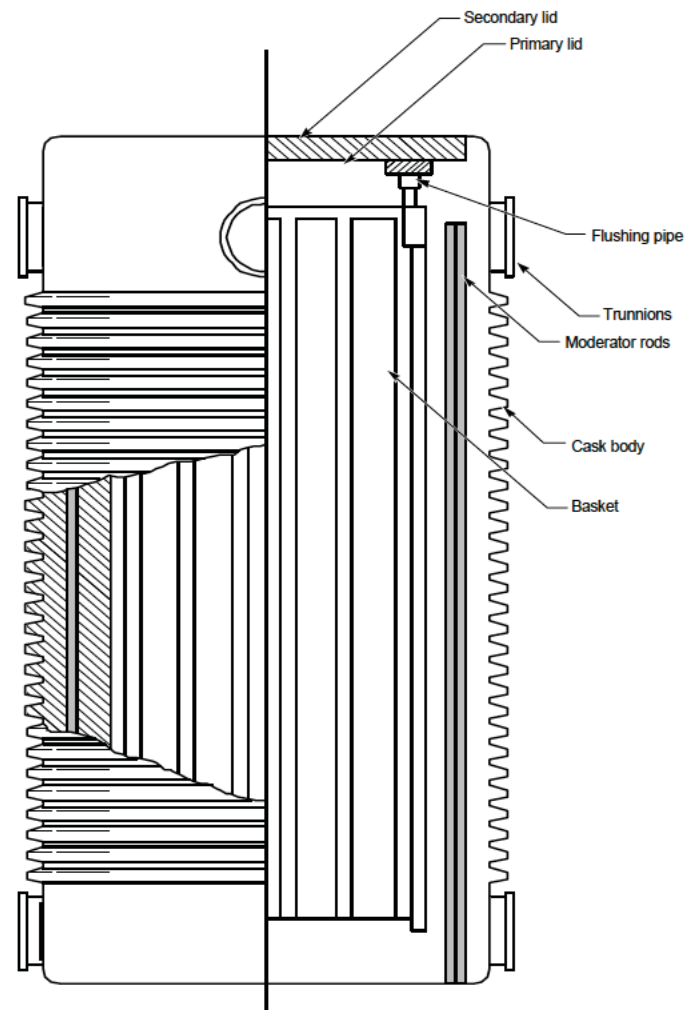

Figure 9. GNS Castor V/21 cask.

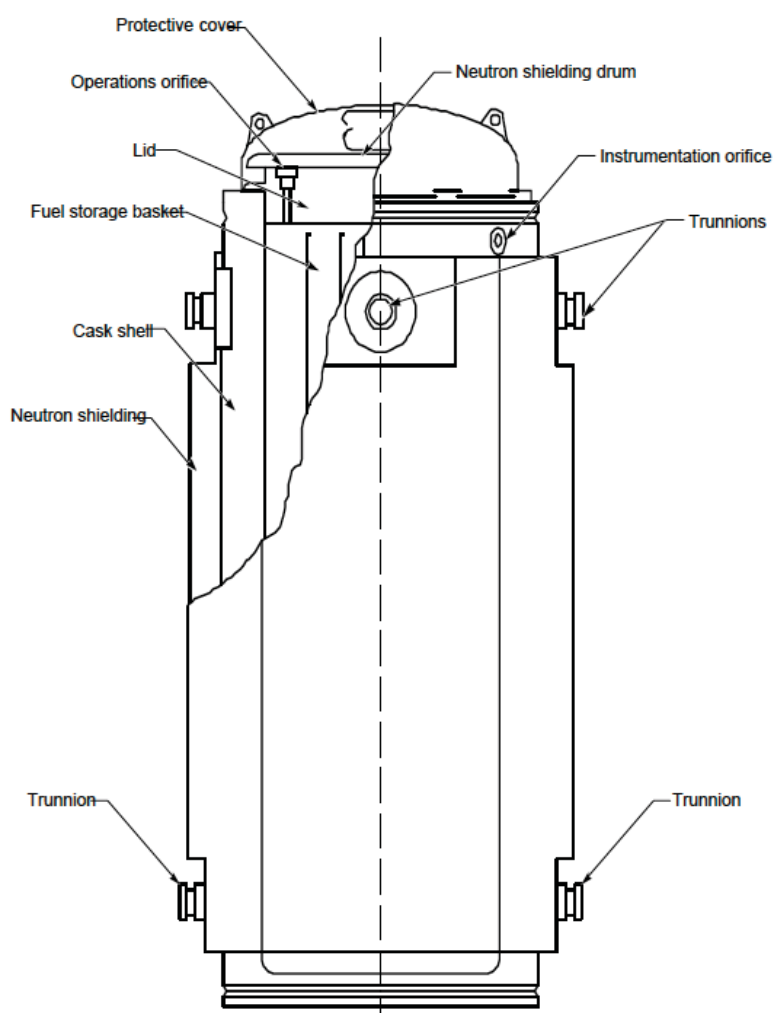

Figure 10. TN-40 storage cask 
Fuel assemblies are physically separated and maintained at specified separation distances by means of fuel storage compartments. The fuel basket is made of borated ( $3 \mathrm{wt} \%$ boron, $2.5 \mathrm{wt} \%$ minimum) aluminum-steel plates. The basket plates are 1-cm thick and copper-coated for improved heat transfer. A different basket design was used for the cask than the one described in the topical safety analysis. Additional performance and structural calculations (including criticality) were performed for the basket. Cask dimensions and specifications are shown in Table 4.

Table 4. TransNuclear Inc. bolted-lid cask dimensions and specifications.

\begin{tabular}{lccc}
\hline \multicolumn{1}{c}{ Description } & TN-32 & TN-40 & TN-40HT \\
\hline Fuel type & PWR & PWR & PWR \\
\# of assemblies & 32 & 40 & 40 \\
Maximum heat load (kilowatts) & 32.7 & 27 & 32 \\
Minimum cooling time (years) & 7 & 10 & 12 \\
Maximum fuel burnup (gigawatt-days per metric ton & 40 & 45 & 60 \\
of uranium) & & & \\
Storage cask: & $4.9(184.0)$ & $4.4(175)$ & $4.6(181.75)$ \\
$\quad$ Length [m] (in.)] & $5.13(201.88)$ & $5.13(202.0)$ & $5.07(199.6)$ \\
$\quad$ Length with protective cover [m. (in.)] & $2.48(97.75)$ & $2.53(99.52)$ & $2.57(101)$ \\
$\quad$ Outer diameter [m. (in.)] & $104.8(231,000)$ & $102.5(226,000)$ & $109.05(242,000)$ \\
$\quad$ Loaded weight [t. (lb)]
\end{tabular}

\section{SUPPORT TO THE TESTING PROGRAM}

\subsection{Fuel Transfer from CPP-603 to the Testing Facility}

The transfer of commercial used fuel components from CPP-603 to a testing facility for characterization can be done using either of two shipping casks: (1) the NAC International, Inc. Legal Weight Truck (NAC-LWT) or (2) the Transnuclear Ft. St. Vrain (TN-FSV) casks. The NAC-LWT has been used in CPP-603 as recently as 2012 for shipment of TRIGA reactor fuel. The TN-FSV was designed for transportation of the Ft. St. Vrain high-temperature gas reactor fuel from Colorado to CPP-603 and is implicitly compatible with the facility equipment. The TN-FSV was certified to transport up to seven PWR fuel rods for transport. Both casks have been used to transfer fuel into HFEF. ${ }^{a}$

Fuel rods would be removed from selected fuel assemblies and placed in cask-specific internal baskets for transport. A basket is then loaded into the shipping cask in the CPP-603 fuel-handling cave. The shipping cask will be lowered onto the transfer cart (fitted with the proper transfer cart insert) using the SF-001 crane. The shipping cask lid bolts will be removed and the cart moved into the fuel-handling cave. Inside the cave, the cask lid will be rigged to the GSF-101 crane hook, lifted off the cask, and set aside. The empty shipping cask basket will be removed from the cask and placed in one of the 24 -in. cave wells. The fuel rods will be loaded into the basket using the CRN-GSF-401 PaR electromechanical manipulator and auxiliary hoist. The basket will be lifted back into the shipping cask using the GSF-401 auxiliary hoist. With the basket in place, the shipping cask lid will be replaced using the GSF-101 crane. The transfer cart will be moved back into the truck bay position.

Operators and health physics technicians will enter the PCS and replace the shipping cask lid bolts and perform radiological surveys. With the lid bolts secured and decontamination completed (if any

\footnotetext{
${ }^{a}$ Transnuclear, Inc., has recently received a certificate of compliance for a new transportation cask: the TN-LC (long cask). To date, none of these casks have been constructed. This cask could be used in the future with little operational impact; the TN-LC designs appear very similar to the NAC-LWT. This cask is not evaluated in this report for the simple reason that none physically exist.
} 
needed), the shipping cask leak check can be performed. Once approved, the PCS will be opened and the shipping cask rigged to the SF-001 crane. The shipping cask will be placed on the transport trailer staged in the truck bay.

Shipping casks can go to MFC or another testing facility for delivery of fuel for testing. Each testing facility will have to receive the cask, open it, retrieve the fuel rods, perform the tests, store fuel segments and samples cut from the fuel rods, and manage/dispose of the commercial high-level waste and other waste streams generated by the work.

Shipping casks going to MFC from offsite facilities can go on the public highway under full DOT compliance. Transport of casks between the INTEC and MFC facilities is done using an onsite transport road with fewer restrictions. Following receipt inspection at MFC, the cask will be driven to the HFEF truck lock.

Once inside the truck lock, a contamination survey will be performed and the cask will be prepared to be lifted with the crane. The crane will be used to lower the shipping cask through the cask cart tunnel hatch and to place the cask onto the cask cart. The crane and rigging will be removed from the cask and the cask lid bolts removed. The appropriate shield ring and bagout sleeve adapter will be installed, and the cask lid will be removed and bagged for contamination control. After closing the cask tunnel hatch, the loaded cask cart will be driven under the main cell to the Window $1 \mathrm{M}$ cask port, where the bagout sleeve will be attached to the main hot cell. Next, the cask system will be purged and tested to confirm the argon atmosphere of the cell is isolated from the ambient air. The shipping cask will be raised to mate to the main. The main hot cell cask port will be opened and the cask basket will be grappled using the hot cell's electromechanical manipulator.

The basket will be moved into the HFEF main cell, where it will be staged in a storage well. The main hot cell cask port will be closed and the shipping cask lowered from the mating position. The inbound steps will be reversed to remove the shipping cask from HFEF.

\subsection{Examination and Sample Preparation}

Fuel rods removed from the basket will be moved through a series of characterization examinations. Characterization is useful for more than one purpose. Not only will characterization be important for UFDC purposes in storage and transportation analyses, these same data can be used to establish characteristics for testing materials in support of future disposition pathways (such as geologic disposal). Any future geologic disposal pathway will require used fuel dissolution data under conditions relevant to the proposed disposal environment. Well-characterized fuel samples are necessary to understand the initial conditions of the material tested. Isotopic data also could be used to benchmark codes for other analyses (e.g., ORIGIN or SCALE).

This section addresses characterization of fuel rods at HFEF. The basic elements of fuel characterization include nondestructive and destructive examinations.

Nondestructive examinations include the following:

- Visual examination

- Eddy current analysis

- Neutron radiography

- Gamma radiography

- Metrology (length, diameter).

Destructive examinations begin with internal rod pressure, fission gas analysis, and void volume. 
Following interpretation of these data, further destructive examination is conducted in select areas. This involves cutting segments and smaller samples from the fuel. Next, samples are prepared for the examination to be conducted. The examinations conducted include the following:

- Optical microscopy

- Electro-optical examinations

- Chemical and radiochemical assay.

These exams will provide a thorough understanding of the characteristics of the fuel rod. Each provides information that will inform the investigator of the surface condition of the fuel clad.

- Visual inspection documents the surface condition of the clad, providing visual reference points for the investigator, indications of surface damage or clad breach, the presence of surface coatings (e.g., CRUD or oxidation).

- Eddy current analysis provides a measure of the thickness of the oxide layers on the clad and characterized profiles of surface defects on the clad.

- Neutron radiography provides a look at the fuel rod internals. It indicates any gross fuel pellet failure, gives a preliminary look at the pellet-clad interface, and provides clear reference points for future destructive examination (e.g., where to cut).

- Gamma radiography provides a semi-quantitative measure of the fuel burnup and indications of any anomalies during in-core operation. It also can determine if there has been any migration of radionuclides that might indicate a fuel pellet failure; however, this is unlikely with modern fuels.

- Metrology is useful to determine fuel rod length and diameter changes that result from in-core performance.

- The internal gas is sampled to determine the fission gases present, the internal rod pressure (to determine changes from the as-fabricated condition), and free void volume used along with the gas species to determine fission gas yield.

- Optical microscopy is useful to characterize both the clad and fuel. The clad is analyzed for the presence and orientation of hydrides and for defects and cracking. The pellet-clad interface is examined to understand the extent of the interaction. The fuel pellets are analyzed for cracking and the presence of any rim restructuring (high burnup fuels).

- Electro-optical examinations are conducted to determine the presence of 5-metal particles and gas bubbles in the fuel.

- Chemical and radiochemical examinations are conducted to determine fuel burnup (typically Nd-148) and fission products to provide a baseline for other testing and analysis.

At HFEF, post-irradiation examination equipment is located at several windows (see Figure 11); the windows are as follows:

- Window 2M, sample preparation for microscopy (optical microscopy is conducted at the metallography hot cell, located north of the main hot cell).

- Between Windows 3M and 4M is the gas assay and recharge system that uses a laser to puncture a fuel rod and perform the gas pressure measurement, gas sampling (the sample is sent to Analytical Laboratory for mass analysis), and void volume determination.

- Window 4M, neutron radiography. Neutrons are provided by the neutron radiography reactor, located in the basement in a water pool just north of the main hot cell. A beam tube brings the beam of neutrons from the reactor into the hot cell. 


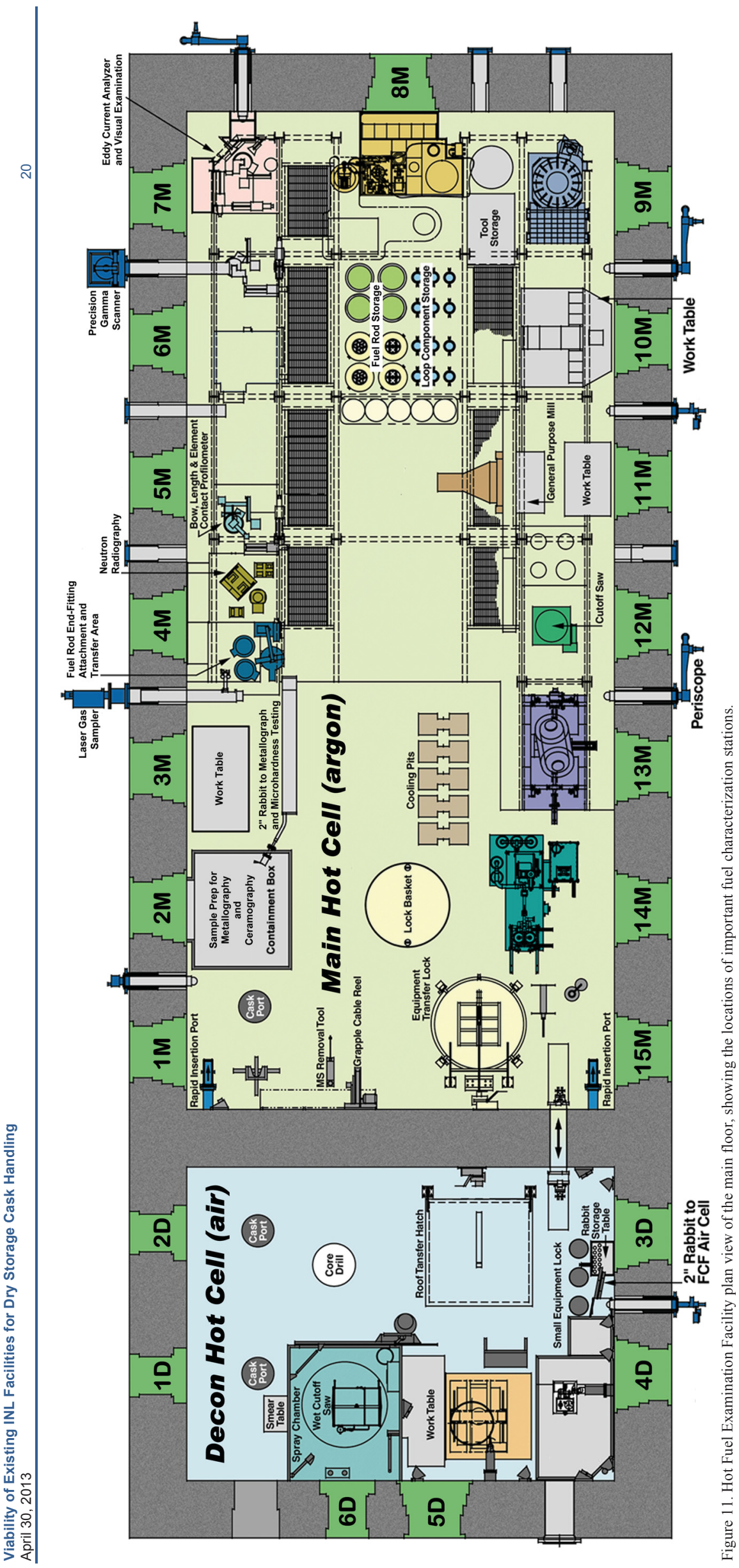


- Window 5M, metrology. A contact profilometer is used for this purpose.

- Window 7M, gamma radiography.

- Window 7M, eddy current analysis and visual examination. A new eddy current and visual examination station are under construction and will replace obsolete systems late in 2014.

- Window $11 \mathrm{M}$ has a general purpose table that is used for cutting, length measurements, and mounting additional fixtures to fuel rods that are needed to conduct the other examinations.

Fuel rods and fuel samples needed for further testing will be staged in storage wells. Samples to be shipped to other laboratories can be sent in shipping casks or packaged in radioactive material shipping containers (such as 9977 drums).

\subsection{Preparation for Testing Commercial Fuel}

Operations similar to those described in this report have been performed often and recently at INL. Some revisions to equipment and procedures will be required to handle the dry storage casks (which are larger than what has been handled at INL before) and the fuel rods (which are longer than what has been handled at INL before). The most significant changes to equipment and procedures will occur at CPP-603 for the larger casks. Those changes are described in Sections 4 through 6 of this report. Shipping casks, trailers, and cask inserts exist for the NAC-LWT and the TN-FSV at CPP-603 and HFEF.

HFEF was constructed to handle fuel (e.g., elements, pins, or rods, depending on the reactor type) in a vertical manner. As the commercial nuclear industry has matured, fuel rods have progressively gotten longer. At the time HFEF was constructed, fuel rods were seldom longer than 12.5 to 13 - $\mathrm{ft}$ long (3.81 to $3.96 \mathrm{~m})$. Today, fuel rods can exceed $14 \mathrm{ft}$ in length $(4.27 \mathrm{~m})$; however, those longer fuel rods represent less than $10 \%$ of the world's nuclear fuel, with few reactors in the United States being capable of using fuel of that length. ${ }^{[5]}$ Further, only one shipping cask is certified for use in the United States today for smaller shipments of singular fuel rods up to assembly quantities (the NAC-LWT); that cask has an internal cavity that is $15.1 \mathrm{ft}$ in length $(4.6 \mathrm{~m})$. The basket takes up nearly $1 \mathrm{ft}(30 \mathrm{~cm})$ of that space, making 14-ft fuel rods about the longest that can be shipped within U.S. DOT regulations. ${ }^{\mathrm{b}}$ Therefore, having the ability to handle fuel rods up to $14 \mathrm{ft}$ in length would ensure INL could work with fuel from over $90 \%$ of the commercial reactors in the world. In the future, fuel from new reactor designs (such as the Westinghouse AP1000) will present challenges, because that fuel is just over $15 \mathrm{ft}(4.57 \mathrm{~m})$ in length. No shipping cask today can accommodate such a long fuel rod.

Each of the characterization stations needed within HFEF was evaluated for the ability to accommodate 14-ft long fuel rods. Each of the stations can accommodate fuel rods of that length with the exception of the gamma radiography station. The gamma radiography sample stage only can accommodate fuel rods up to $13.5 \mathrm{ft}$ in length. The sample holder for this particular stage can be modified to accommodate longer fuel rods. This modification would not be made until a fuel rod of that length was identified for examination at HFEF. As configured, the gamma radiography capability can accommodate the majority of PWR and BWR fuels in service in the U.S. nuclear fleet.

To prepare for conducting characterization operations, procedures will require updating and some will need to be developed (e.g., the new visual examination and eddy current analysis procedures). Training for nuclear operators would be conducted. INL applies a graded approach to operational readiness, and reviews will be conducted to ensure readiness at each stage of the characterization campaign (e.g., cask receipt and handling, characterization station operation, fuel rod handling, and fixture mounting). No

\footnotetext{
${ }^{\mathrm{b}}$ It is important to note that shipping an assembly of fuel inside the NAC-LWT further limits the fuel rod length. Assembly hardware reduces the practical fuel rod length to about $12 \mathrm{ft}$ when shipping in the NAC-LWT. Therefore, for longer fuel rods, it is necessary to remove the rods from the assembly at the utility spent fuel pool and ship those rods in a "loose" fuel rod basket. If that fuel is high burnup, no more than 25 rods can be shipped inside the NAC-LWT cask (both PWR and BWR). That quantity is sufficient for the purposes of the UFDC.
} 
transport plan will be needed because both casks are (or were in the case of the FSV cask) DOT-licensed Type B packages.

\section{ASSUMPTIONS}

The following key assumptions have been used in determining the viability of the INL capabilities to handle dry storage casks:

1. As discussed in Section 3.1, only PWR fuel would be contained in larger dry storage casks coming to INL from offsite.

2. Casks shipped to INL will be received at CFA and transferred via truck/heavy haul trailer to CPP-603.

3. Because only a few casks will be examined, improvements to the facility infrastructure (e.g., installation of a 125-ton crane or rail restoration) and the associated operations and maintenance cost are not justified.

4. DOE shipping requirements will apply once the fuel is on the INL site (DOT regulations apply outside INL).

5. Four casks are considered: REA-2023, Castor V/21, TN-32, and TN-40HT.

6. TN-32 or TN-40HT will not be delivered to INL for over 5 years.

7. National Environmental Policy Act authorization will be limited to an environmental checklist.

8. The facility Environmental Protection Agency-approved air permit is adequate for the work; no significant effluent streams are anticipated that would require a revision.

9. Casks will have less than $500 \mathrm{mrem} /$ contact when closed.

10. Casks will have greater than $10,000 \mathrm{R} /$ hour with the lid off and fuel directly exposed; shielding in the fuel-handling cave is adequate.

11. Fuel assemblies and fuel rods are surface contaminated. There is a standard grapple that can handle the fuel assemblies contained in the storage casks.

12. CPP-603 is seismically qualified and will not need modification outside the specific needs of this project. Heating, ventilating, and air conditioning; electrical; and so forth are all adequate.

13. The 10 CFR 830-compliant documented safety analysis will require some modification, but not a major rewrite.

14. Construction and all readiness actions will be complete 6 months prior to need.

15. No existing CPP-603 facility crane is capable of lifting the large dry storage casks (i.e., TN-32 and TN-40HT).

16. The GSF-101 and 401 cranes have adequate lift capacity and dexterity for all purposes inside the fuel-handling cave.

17. The transfer car will support the load of the heavier dry storage casks.

18. A temporary gantry crane of sufficient capacity (i.e., 125 ton) will fit within the facility and will be used for lifting the large dry storage casks.

19. Exposure of the fuel to air while in the cave is acceptable for the short time it will be exposed.

20. No modifications will be required for the CPP-603 cave storage wells beyond adding a "hat" to raise the enclosed height to accommodate the length of the commercial fuel rods. 
21. Issues related to the 1995 Settlement Agreement are being addressed outside the scope of this evaluation.

22. Project funding is an operating expense and not a capital acquisition.

\section{OPERATIONS APPROACH}

The following operations approach is generalized and includes only those details necessary to form a basic understanding of the viability described in this report.

- The campaign begins with arrival of the transport train at INL's CFA rail yard. The impact limiters are removed and the loaded cask is transferred to a heavy-haul truck/trailer. The truck/trailer transports the cask to CPP-603 via an approved transport route.

- Prior to delivery of a cask to CPP-603, the appropriate insert is placed in the opening of the transfer car and all gantry crane rigging for the lift is identified, inspected, and staged for the lift.

- The truck/trailer enters CPP-603 and parks under the gantry, the cask is off-loaded, and the cask condition is inspected. Optionally, gas sampling can be done prior to putting the cask into PCS.

- PCS will be opened and the cask lowered onto the transfer car. A gas sample of the cask interior will be taken and analyzed. The rigging and outer lid are removed; PCS is closed; and the cask and car are moved into the fuel-handling cave.

- Once in the fuel-handling cave, the cask lid is removed and set aside using the CRN-GSF-101 in-cave crane.

- CRN-GSF-101 will be disengaged from the lid and the hook will attach to the fuel assembly grapple tool.

- In-cave video cameras will perform video inspection of the exposed fuel assemblies with the lid removed.

- CRN-GSF-101 will be positioned to attach the grapple tool to a selected fuel assembly. If necessary, the CRN-GSF-401 electromechanical manipulator will be used to facilitate the attachment.

- When engaged with a fuel assembly, CRN-GSF-101 will lift the assembly in defined increments to allow progressive video inspection.

- When the assembly is clear of the cask, it will be placed in a specified cave floor well. This process will be repeated according to data needs.

- Depending on data needs, a high-resolution, radiation-resistant camera will be used to inspect the cask interior at the empty fuel basket positions.

- If project scope includes fuel rod removal from an assembly, tools will have been developed, tested and staged in the cave for this task. The required fixtures would be attached to the assembly and selected rods removed and placed in an adjacent cave floor well. The assembly(ies) would be returned to the position from which it was removed, or an assembly could be transported to HFEF for in-depth examination or further testing.

- The inner lid is replaced and the cask is moved to the PCS, where the atmosphere inside the cask is restored to the initial, as-received condition.

- The outer lid is replaced and the cask is leak tested.

- The cask is surveyed for radioactive contamination and decontaminated, as needed.

- PCS is opened, the rigging reattached, and the cask is moved out of the transfer car and onto the tuck/trailer in the truck bay. 
- The truck/trailer will deliver the cask either to the CFA rail yard or to the CPP-2707 cask storage pad.

- The steps detailed above are similar for moving the REA-2023 or Castor V/21 casks currently stored on the CPP-2707 storage pad.

\section{ENGINEERING}

\subsection{Facility Overview}

The CPP-603 functional areas include the (1) truck bays (including cask receiving area, east/west truck bay, and north/south truck bay), (2) cask transfer pit and PCS, (3) fuel-handling cave, (4) fuel storage area, (5) control room/instrument room, (6) crane maintenance area, and (7) decontamination pad.

This report focuses on the east/west truck bay (Figure 4). Fuel or materials to be stored in CPP-603 are generally received in transportation packages in the cask receiving area on a transport vehicle. The impact limiters will be removed and the cask upended prior to entering CPP-603. The vehicle is brought into the cask receiving area through any of the overhead doors. Radiation surveys are performed and package identity is confirmed. The transport packaging and equipment is disassembled as required for cask handling operations. Cask handling operations at CPP-603 include those activities performed to move the fuel-loaded cask between the transport position on the transfer vehicle and the cask transfer car. These activities include releasing the cask from the transport vehicle (removal of tie-down devices), removal of rigging, lifting, and moving the cask. The cask is prepared for placement into the cask transfer car by rigging it to the portable gantry crane.

\subsection{Cask Transfer Car}

The cask transfer car and associated cask transfer car adapters are designed to meet the dimensional and load requirements of the cask. The TN-40HT outside diameter will fit in the transfer car. This will require an adapter that will be integrated with the lifting mechanism.

\subsection{Truck Bay Floor Capacity Evaluation}

After comprehensive literature review, the floor capacity is considered to be approximately 6,100 psf. Assuming the truck bay area has the same floor capacity, the pressure due to the cask is estimated as follows:

- $\mathrm{D}=98.5$ in. $=8.2 \mathrm{ft}$

- $\mathrm{A}=\left(\pi^{*} \mathrm{D}^{2}\right) / 4=52.9 \mathrm{ft}^{2}$

- $\mathrm{Wt}=125$ tons $=250,000 \mathrm{lb}$

- $\quad \mathrm{P}=\mathrm{Wt} / \mathrm{A}=4,725 \mathrm{psf}$

Based on the simplified evaluation, the bay floor is capable of handling the weight of the cask.

\subsection{Proposed Gantry Crane}

Although the edge of the transfer is near the fuel transfer cave wall, it is feasible to have a custom-built gantry hydraulic crane lift the cask and lower it to the transfer car. A possible custom-built gantry crane configuration is presented in Figure 12.

\subsection{Ventilation}

The CPP-603 ventilation system provides confinement ventilation and heat removal for CPP-603 per applicable Department of Energy and national standards. The directed air-flow maintains a sufficient negative pressure to prevent the release of potentially contaminated air from the facility during all operating modes in accordance with the Department of Energy Nuclear Clean Air Handbook. The exhaust 
air system also incorporates an air monitoring system, located in the exhaust stack, that samples the exhaust air stream for radionuclides. The facility ventilation system was upgraded in 2004 to replace an existing roof-mounted ventilation exhaust system with a new ground level ventilation system housed in a metal structure, including an exhaust air sampling system. The truck bay does not require ventilation. The PCS/transfer car pit area has a ventilation system that is operated independently of the main building ventilation system.

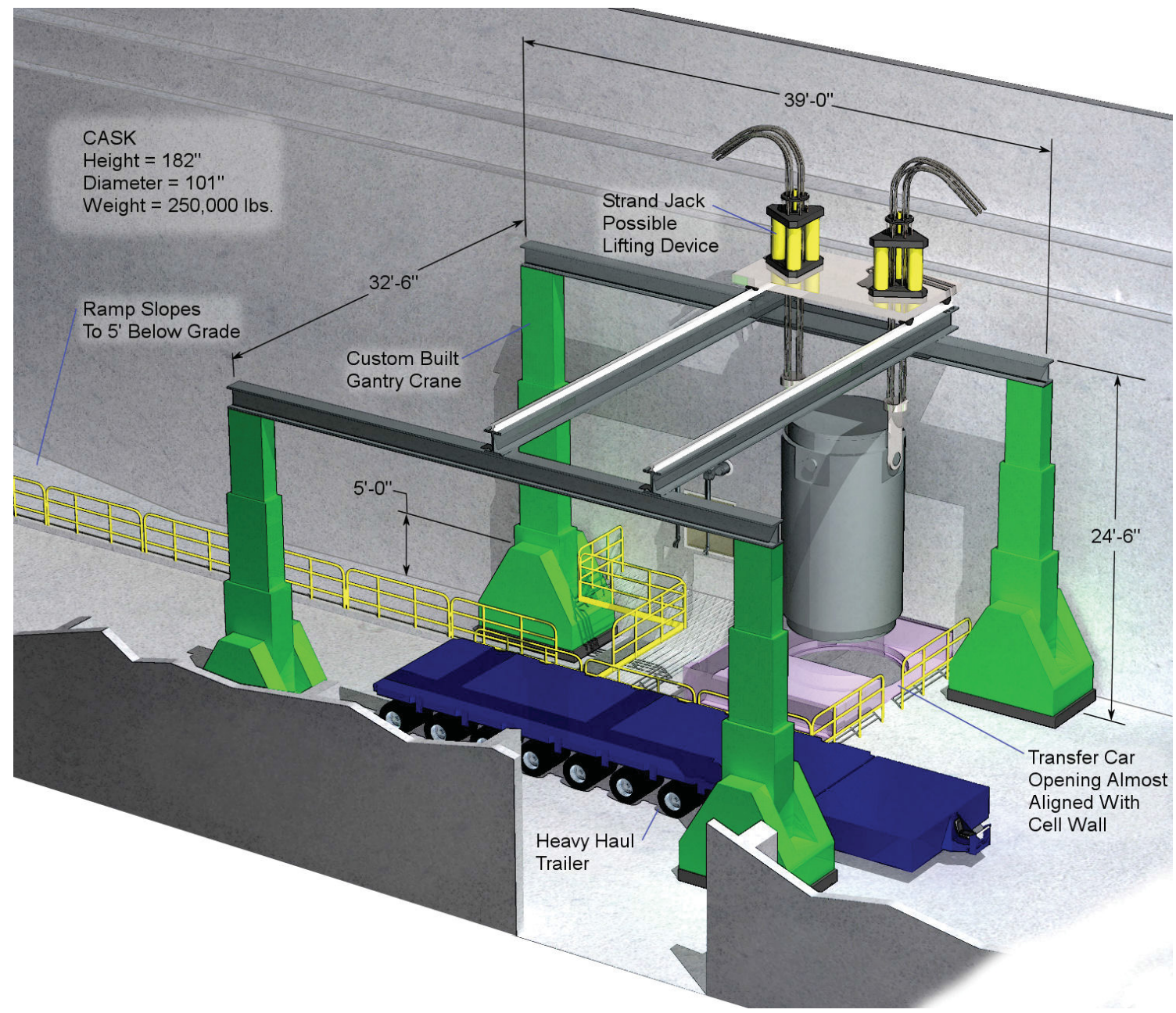

Figure 12. Possible layout of a gantry crane.

\section{COST}

The estimated cost range to mobilize the necessary resources and examine the first cask and its contents is $\$ 8.4$ to $\$ 16$ million. This cost range includes the following:

- Development of safety documentation, design, and fabrication of specialized fixtures, training, and readiness testing

- Transferring the cask from a rail car to CPP-603

- Setting up a gantry crane to move the cask from the truck onto the transfer car in CPP-603, transferring the cask into the fuel-handling cave

- Performing observations of the fuel assemblies and cask interior 
- Resealing the cask lid and returning the cask to the rail car or the CPP-2707 cask storage pad to continue the storage demonstration.

The additional cost associated with shipping fuel to HFEF would result in a cost range of $\$ 9.8$ to $\$ 18$ million. These additional costs include the following:

- Ship fuel from CPP-603 to HFEF

- Minor modifications to equipment.

Costs not included are as follows:

- Costs to ship the cask to or from INL

- Perform the non-destructive tests described in Case 2

- Perform the destructive testing of samples retrieved from the fuel assemblies as described in Case 3.

These cases are not evaluated because the kinds of examinations required have not been defined and will be developed closer to the time of cask opening. The campaign will require less than 3 years to complete; therefore, this cost estimate is in 2012 dollars (i.e., no escalation for inflation).

The cost estimate is based on an acquisition strategy that leverages subcontractor expertise to maximize safety and quality, while minimizing cost and schedule. Conceptual and preliminary design will be performed by INL engineering to develop the statements of work and requirements. Final design, fabrication, and installation of the fixtures (e.g., transfer car inserts and lifting fixtures in the fuel-handling cave) will be performed by subcontractors experienced in nuclear facility design and construction. Likewise, design, assembly, testing, and operation of the portable gantry crane will be performed by a heavy-haul contractor with experience in the rigorous safety and quality requirements of a nuclear facility.

A significant portion of the cost is in developing the process, hardware, and configuration to conduct a one-cask campaign. If additional casks are to be examined, the incremental cost will be modest, depending on when the decision to examine more casks is made. If the gantry crane is still in place, the additional cost would be very small, but even remobilizing the gantry crane at a later date will be much less expensive than the cost of initial cask examination. Likewise, the incremental cost of cask handling for additional study as described in Case 2 and Case 3 is very small once the cask is inside the fuelhandling cave.

The cost estimate for this project, which is in the earliest stage of development, is based on expert opinion supported by vendor budgetary quotes and parameters from similar projects. The cost estimating team, led by a senior cost estimator, included representatives from engineering, operations, and project management. The estimate is presented as a range to reflect the preliminary definition of the project. The lower end of the range could be achieved if conceptual engineering identifies significant reductions in the complexity of the fixtures needed to handle the cask or a streamlining of the operations needed to move the cask onto the transfer car. The upper end of the range could be realized if operational or procedural challenges associated with the chosen methodology develop.

The maturity level of the project definition does not provide sufficient information to apply a cost estimate classification of 1 through 5 in accordance with the deterministic criteria identified by the American Association of Cost Engineering. This estimate does conform to criteria required of a Preliminary Class 5 estimate as described by INL procedures. This classification is consistent with the purpose of this estimate to develop cost data in support of a proposal that may be considered for moving the project forward into the initiation stage. 


\section{CONCLUSIONS}

CPP-603 was built to receive and handle spent nuclear fuel. The existing bridge crane is not rated for the weight of a commercial used fuel storage and transportation cask. Facility operations can be readily modified to handle a heavier, commercial fuel cask (such as the TN-32 or TN-40HT) with the use of a portable gantry crane operated by an experienced heavy-haul subcontractor. This can be accomplished with a reasonable schedule and incremental cost that can be repeated for additional casks, if desired.

The portable gantry crane can be easily modified to accommodate different cask configurations. The PCS can be modified to provide containment prior to moving the cask into the cell for removing lids, sampling the atmosphere, or other operations that may require reorienting the position of the cask outside of the fuel-handling cave, while protecting against release of radioactive material.

The use of a portable gantry crane inside CPP-603 was chosen to provide the lowest cost of a one-cask campaign, while leaving flexibility to handle future casks for a relatively small incremental cost. Demobilizing the gantry crane after the campaign leaves CPP-603 intact to continue its existing operation, avoids the potential long-term facility and equipment maintenance costs that could be applied if the facility was modified significantly for this project.

Case 1, Observation, is the principal subject of this report, because observation of the fuel assemblies and cask provide the minimum information needed to demonstrate the long-term effects of dry storage on high burnup UNF. The small incremental cost and schedule to execute Case 2, Non-Destructive Examination, and Case 3, Sampling for Destructive Examination, provide an efficient way to gather confirmatory data.

\section{REFERENCES}

1. "Used Fuel Disposition Campaign - Review of Used Nuclear Fuel Storage and Transportation Technical Gap Analysis," FCRD-USED-2012-000215, July 31, 2012.

2. "Used Fuel Disposition Campaign - Gap Analysis to Support Extended Storage of Used Nuclear Fuel," Revision 0, FCRD-USED-2011-000136 (PNNL-20509), Pacific Northwest National Laboratory, January 31, 2012.

3. EDF-9258, "Conceptual Structure Analysis for Crane Upgrade Capacity of CPP-603 East-West Truck Bay,” Revision 0, J. L. Coleman, Idaho National Laboratory, July 7, 2009.

4. TEV-1187, "Feasibility of Using the Irradiated Fuel Storage Facility (IFSF) to Remove Commercial Used Fuel from the REA-2023 Cask, " Idaho National Laboratory, March 15, 2011.

5. Nuclear Engineering International, September 2010 and September 2004, Fuel Design Data. 